University of Tennessee College of Law

Legal Scholarship Repository: A Service of the Joel A. Katz Law Library

UTK Law Faculty Publications

$1-2019$

\title{
The Wolf Act Amendments to the U.S. International Religious Freedom Act: Breakthrough or Breakdown?
}

Robert Blitt

Follow this and additional works at: https://ir.law.utk.edu/utklaw_facpubs

Part of the Law Commons

\section{Recommended Citation}

Blitt, Robert, "The Wolf Act Amendments to the U.S. International Religious Freedom Act: Breakthrough or Breakdown?" (2019). UTK Law Faculty Publications. 168.

https://ir.law.utk.edu/utklaw_facpubs/168

This Article is brought to you for free and open access by Legal Scholarship Repository: A Service of the Joel A. Katz Law Library. It has been accepted for inclusion in UTK Law Faculty Publications by an authorized administrator of Legal Scholarship Repository: A Service of the Joel A. Katz Law Library. For more information, please contact eliza.boles@utk.edu. 


\title{
UNIVERSITY of PENNSYLVANIA JOURNAL of LAW \& PUBLIC AFFAIRS
}

\section{Vol. 4 \\ Jan. 2019 \\ The Wolf Act Amendments to the U.S. INTERNATIONAL RELIGIOUS FREEDOM ACT: BREAKTHROUGH OR BREAKDOWN?}

No. 2

\author{
Robert C. Blitt ${ }^{*}$
}

This Article takes a critical look at the major changes brought about by recent amendments to the International Religious Freedom Act of 1998 (IRFA). The first section briefly traces IRFA's key features and operation since its enactment, including an overview of the statute's institutions and reporting and sanctioning mechanisms. This section also highlights the ongoing debate regarding IRFA's legitimacy and offers a summary of the major criticisms leveled against the statute, as well as the responses raised in its defense. With this background in place, the Article turns to an analysis of the legislative history surrounding the Frank $R$. Wolf International Religious Freedom Act (Wolf Act) between 2015 and 2016. This bipartisan legislative initiative envisioned a wide range of amendments intended to address some of IRFA's past shortcomings. Among the changes initially put forward, IRFA's narrow focus on states would be expanded to include violent nonstate actors responsible for violating freedom of religion or belief. In addition, the original Wolf Act called for boosting the responsibilities and profile of IRFA's institutional actors, increasing funding for the promotion

\footnotetext{
* Professor of Law, University of Tennessee College of Law. The author was USCIRF's International Law Specialist from 2004-2006. The impetus for this project flowed from participation in an academic seminar entitled "War and Peace and Religion: Religious Freedom during Russian-Ukrainian Conflict" held at Yaroslav the Wise National Law University in Kharkiv, Ukraine in 2018. The author extends thanks to his colleagues at UT College of Law for the helpful feedback they provided during presentation of a draft version of this paper in June 2018. Tremendous thanks are also due to Amanda LeSavage and the University of Pennsylvania Journal of Law \& Public Affairs' team, who prepared this manuscript for publication in record time.
} 
of international religious freedom activities, mandatory religious freedom training of State Department officials, and a significant reduction of executive discretion. As a review of this legislative history will demonstrate, however, many of the changes originally proposed would be either diluted or altogether deleted, the victims of bad design or competing political interests. The final content of the Wolf Act as enacted represents an ambivalent renewal of IRFA's original promise "to use and implement appropriate tools in the United States foreign policy apparatus . . . to promote respect for religious freedom by all governments and peoples. "I In conclusion, the Article posits some of this ambivalence may be alleviated or partially remedied based on how IRFA's primary institutional actors turn to the task of implementation. At the same time, securing a more definitive assertion of the central role of religious freedom in U.S. foreign policy as envisioned in the original Wolf Act will likely require a renewed, more concerted and committed second effort by Congress.

INTRODUCTION 152

I. TWENTY YEARS OF IRFA: BRICKBATS AND BOUQUETS 154

II. ThE EFFORT TO AMEND IRFA, 2015-2016: A LEGISLATIVE History ON THE ROAD TO PUBLIC LAW 114-281

A. Wolf Act as Originally Introduced - February 2015 .................... 168

B. Engrossed in House - May 2016................................................. 182

C. Senate Revisions - December 2016 ............................................. 191

D. Public Law 114-281: Outcome of Congressional Negotiations ....195

CONCLUSION.

\section{INTRODUCTION}

As one of his final acts as president, Barack Obama authorized the first major overhaul of the International Religious Freedom Act (hereinafter "IRFA") since its passage twenty years ago. ${ }^{2}$ This Article will take a critical look at the major changes brought about by this overhaul and argue they fail to fully deliver on the objectives attached to the original effort to amend IRFA.

\footnotetext{
${ }^{1}$ International Religious Freedom Act of 1998, Pub. L. No. 105-292, §2(b)(5), 112 Stat. 2787, 2790 (1998) (codified at 22 U.S.C. § 6401).

${ }^{2}$ Frank R. Wolf International Religious Freedom Act, Pub. L. No. 114-281, 130 Stat. 1426, 1426 (2016) (codified at 22 U.S.C. § 6401).
} 
Part One of this Article briefly introduces IRFA's key features and operation prior to the 2016 amendments, including an overview of the institutions and reporting and sanctioning system created by the statute. This section will also highlight the debate over IRFA's legitimacy and trace the major criticisms leveled against the statute since its inception, as well as the responses raised in its defense.

With this background in place, Part Two will review the legislative history surrounding the Frank R. Wolf International Religious Freedom Act (hereinafter "Wolf Act") between 2015-2016. ${ }^{3}$ This bipartisan legislative initiative envisioned a wide range of amendments intended to strengthen IRFA and respond to past shortcomings. Among the changes initially put forward, IRFA would move beyond its narrow focus on states to include scrutiny of violent nonstate actors responsible for violating freedom of religion or belief. In addition, the original Wolf Act called for the appointment of a religious freedom czar within the National Security Council, a significant boost to the profile and standing of the Ambassador at Large for International Religious Freedom, and guaranteed minimum funding and staffing for the Office of International Religious Freedom and for programs intended to promote international religious freedom. Further, the bill included mandatory religious freedom training of State Department officials and a significant reduction in executive discretion, including a new tier system that would authorize automatic designation of certain countries as Countries of Particular Concern. As this legislative history will demonstrate, many of the proposed changes would go on to be diluted or altogether deleted, the victims of bad design or competing political interests.

In assessing the final content of the Wolf Act amendments to IRFA, this Article takes a middle ground. The changes authorized by Congress afford IRFA some long-needed basic upgrades and updates. However, many of the more innovative and forceful original proposals proved too overbroad or simply too bold to successfully navigate the negotiation process. Ultimately, what remains of the amendments represents an ambivalent renewal of IRFA's original promise "to use and implement appropriate tools in the United States foreign policy apparatus ... to promote respect for religious freedom by all governments and peoples." Some of this ambivalence may be alleviated or partially remedied by how IRFA's primary institutional actors opt to implement the various amendments. At the same time, securing a more definitive assertion of the central role of religious freedom in U.S. foreign policy as envisioned in the original Wolf Act may require a more concerted and committed second effort by Congress.

\footnotetext{
${ }^{3}$ Named for the now-retired sponsor of the original 1998 legislation, Rep. Frank Wolf (R-VA).

${ }^{4}$ International Religious Freedom Act §2(b)(5), 112 Stat. at 2790 (codified at 22 U.S.C. § 6401).
} 


\section{TWENTY YEARS OF IRFA: BRICKBATS AND BOUQUETS}

For two decades, monitoring and reporting on international violations of freedom of thought, conscience and religion or belief has been a formalized component of the foreign policy of the United States government. This phenomenon can be traced back to bipartisan passage of the IRFA, ${ }^{5}$ which President Bill Clinton signed into law in 1998. Among other things, IRFA created new institutional actors dedicated to collecting data and advising the U.S. government on violations of religious freedom in foreign countries. These actors included an Office on International Religious Freedom (OIRF) and Ambassador at Large for International Religious Freedom within the Department of State, an independent, bipartisan Commission on International Religious Freedom (USCIRF), and a Special Adviser on International Religious Freedom within the National Security Council. ${ }^{6}$

With these new institutions in place, IRFA mandated that OIRF prepare an annual report containing "detailed information with respect to matters involving international religious freedom", in every foreign country, including:

- The status of religious freedom;

- An "assessment and description of the nature and extent of violations of religious freedom";

- A "description of United States actions and policies in support of religious freedom in each foreign country engaging in or tolerating violations of religious freedom"; and

- "A description of any binding agreement with a foreign government entered into by the United States."

To undertake this global reporting obligation, IRFA further required that U.S. missions standardize reporting and "thoroughly investigate reports of violations of the internationally recognized right to freedom of religion." "This

\footnotetext{
${ }^{5}$ See generally, $i d$. The bill passed in the Senate 98-0. Originally introduced in the House of Representatives as an Act "to establish an Office of Religious Persecution Monitoring." Freedom from Religious Persecution Act of 1997, H.R. 2431, 105th Cong. (1997).

${ }^{6}$ According to USCIRF, "no administration since [IRFA's] enactment has named an adviser focusing only on international religious freedom; instead, all have assigned the issue to an NSC director as part of a broader human rights and multilateral affairs portfolio." U.S. COMM. ON INT'L RELIGIOUS FREEDOM, ANN. REP. 11 (2017).

${ }^{7}$ International Religious Freedom Act of 1998, Pub. L. No. 105-292, §102, 112 Stat. 2787, 2793 (codified at 22 U.S.C. § 6412).

${ }^{8}$ Id.

${ }^{9}$ Id. at 2794.
} 
point is critical inasmuch as it signaled Congress' intention to measure violations of freedom of religion and belief not based on the yardstick of U.S. law, but rather as articulated under the Universal Declaration of Human Rights (UDHR) and the International Covenant on Civil and Political Rights (ICCPR). ${ }^{10}$

Where this reporting reveals a foreign government has engaged in or tolerated violations of religious freedom, IRFA requires that the president take action. ${ }^{11}$ Title IV of IRFA provides the president with a variety of measures intended to "respond to the nature and severity of the violations of religious freedom"12 at issue, with an eye towards securing the "cessation of such violations." 13 In the case of governments identified as violating religious freedom, the statute provides the president with access to 15 specific actions, ranging from "soft" actions, such as "private demarche" and "the delay or cancellation of working, official, or state visits," to more pointed steps including prohibiting U.S. procurement from and loans to the targeted government. ${ }^{14}$ As an alternative to these specific actions, IRFA grants the president the open-ended ability to take commensurate action or to "negotiate and enter into a binding agreement" with the government responsible for violations of religious freedom. ${ }^{15}$

Where the president concludes that a government's action escalates into engaging in or tolerating "particularly severe violations of religious freedom", IRFA requires that the country at issue be designated as a "country of particular concern" (CPC) for religious freedom. ${ }^{16}$ This designation takes

\footnotetext{
${ }^{10} I d$. at $\$ 2(\mathrm{a})(5), 2788$ (codified at 22 U.S.C. 6401). Violations under IRFA include "arbitrary prohibitions on, restrictions of, or punishment for" peaceful religious assembly; expressions of religious belief; changing one's religious beliefs; possession and distribution of religious literature; raising children according to the religious practices of one's choosing; or "detention, interrogation, imposition of an onerous financial penalty, forced labor, forced mass resettlement, imprisonment, forced religious conversion, beating, torture, mutilation, rape, enslavement, murder, and execution" committed on the basis of an individual's religion or belief. Id. at §3(13), 2791 (codified at 22 U.S.C. 6401).

11 In 1999, President Clinton delegated this responsibility to the Secretary of State. See Delegation of Responsibilities Under the International Religious Freedom Act of 1998, 64 Fed. Reg. 47345 (Aug. 17, 1999).

${ }^{12}$ International Religious Freedom Act of 1998, Pub. L. No. 105-292, § 401, 112 Stat. 2787, 2801 (1998) (codified at 22 U.S.C. $§ 6441$ ).

${ }^{13} \mathrm{Id}$. at $2801-2802$.

${ }^{14} I d$. at $\S 405,2806-07$ (codified at 22 U.S.C. $§ 6445$ ).

${ }^{15} \mathrm{Id}$. at 2807.

${ }^{16}$ Under the statute, "particular severe violations" means:
}

"[S]ystematic, ongoing, egregious violations of religious freedom, including violations such as-

(A) torture or cruel, inhuman, or degrading treatment or punishment;

(B) prolonged detention without charges; 
IRFA's "soft" responses off the table. Instead, it commits the president to more forceful action, ranging from the withdrawal, limitation, or suspension of United States development assistance and security assistance to prohibiting U.S. procurement from and loans to the targeted government. ${ }^{17}$ In these "particularly severe" cases, the president may still opt for commensurate action or a binding agreement with the violating government. ${ }^{18}$ At the same time, IRFA also provides the president with the ability to waive any action on designated CPCs where such a waiver would further the purposes of IRFA or be in "the important national interest of the United States."19

As illustrated in the table below, action taken in accordance with IRFA has resulted in the president either authorizing sanctions on certain CPCs or issuing multi-year waivers intended to further the purposes of IRFA or U.S. national interest. In imposing sanctions on designated CPCs, however, the president has virtually never opted to authorize new, IRFA-based sanctions. In 2005, the State Department denied export of defense articles and services covered under the Arms Export Control Act to Eritrea. According to USCIRF, "This was the first, and so far only, unique presidential action under (IRFA) in response to a CPC designation." ${ }^{20}$ Instead, past practice typically has resulted in ordering preexisting sanctions already in place against a country (for reasons unrelated to CPC designation under IRFA) to be "double hatted", and therefore also to reflect the penalty required under IRFA.

The table below also confirms that only 14 countries of the nearly 200 reviewed annually by the OIRF have ever been designated as CPCs. Additionally, the identity of these CPCs has remained relatively static over IRFA's lifetime, with most of them now chronic fixtures on the annually revised CPC list. Of the current ten CPC-designated countries, Burma, China, Iran and Sudan can all be traced back to the original list issued in 1999. Another four countries - Eritrea, North Korea, Saudi Arabia, and Uzbekistan — were added early in the last decade. Only two countries-Tajikistan and Turkmenistanrecently joined the CPC list in 2014 and 2016 respectively.

(C) causing the disappearance of persons by the abduction or clandestine detention of those persons; or

(D) other flagrant denial of the right to life, liberty, or the security of persons."

Id. at 2791 (codified at 22 U.S.C. § 6402).

${ }^{17}$ International Religious Freedom Act $\S 405,112$ Stat. at 2807 (codified at 22 U.S.C. § 6445).

${ }^{18} I d$.

${ }^{19} \mathrm{Id}$. at 2808 (codified at 22 U.S.C. $\S 6445$ ).

${ }^{20}$ U.S. COMM. ON INT'L RELIGIOUS FREEDOM, ANN. REP. 47 (2010). 
Beyond the ten current CPC designations, only four additional countries-Iraq under Saddam Hussain, Afghanistan under the Taliban, the Federal Republic of Yugoslavia (Serbia) under Slobodan Milošević, and Vietnam-have made formal, if short-lived, appearances on the list. The State Department removed the first three designations following military interventions and ensuing regime changes. In the case of Vietnam, after a short two-year stint on the CPC list, the U.S. Department of State heralded improvements derived from a secretly-negotiated binding agreement with the Vietnamese government as a sufficient basis for delisting that country. ${ }^{21}$ The State Department has not added a new country to the CPC list since 2016.

In contrast with State Department practice, the U.S. Commission on International Religious Freedom's (USCIRF) CPC recommendations divulge a far wider variation in the number and identity of states persistently violating religious freedom. For example, USCIRF's most recent annual report endorsed the State Department's ten CPCs and called for six additional states to be added to the list: Central African Republic, Nigeria, Pakistan, Russia, Syria, and Vietnam. ${ }^{22}$ Further to this, the Commission has introduced and maintains its own "Tier 2" listing of countries. According to USCIRF, Tier 2 countries do not rise to the CPC level, but nevertheless have governments identified as engaging in or tolerating serious violations "characterized by at least one of the elements of the 'systematic, ongoing, and egregious' CPC standard." 23 In 2018, the Commission included 12 countries within this Tier 2 designation. ${ }^{24}$

From USCIRF's perspective, "Over time, the disparities between USCIRF's CPC recommendations and the State Department's CPC designations have grown, with USCIRF consistently recommending more countries than the secretary designates." 25 However, IRFA does not make

\footnotetext{
${ }^{21}$ According to USCIRF, "Vietnam is unique in that it is the only [country] removed from the CPC list due to diplomatic activity." U.S. COMM. ON INT'L RELIGIOUS FREEDOM, RELIGIOUS FREEDOM IN VIETNAM: ASSESSING THE COUNTRY OF PARTICULAR CONCERN DESIGNATION 10 YEARS AFTER ITS REMOVAL, 1 (2017) [hereinafter U.S. COMM. ON INT'L RELIGIOUS FREEDOM, 10 YEARS AFTER]. Moreover, Vietnam is also the only "known use of a binding agreement pursuant to a CPC designation under IRFA." Id. at 3. See also Press Release, U.S. Comm. On Int'1 Religious Freedom, Vietnam: USCIRF calls on the State Department to make "secret" May 5 agreement with Vietnam public (Jun. 22, 2005), https://www.uscirf.gov/news-room/press-re leases/vietnam-uscirf-calls-the-state-department-make-secret-may-5-agreement [https://perma.c c/5GU8-3TGU].

${ }^{22}$ U.S. COMM. ON INT'L RELIGIOUS FREEDOM, ANN. REP. 3 (2018).

${ }^{23} I d$.

${ }^{24}$ Id. ("Afghanistan, Azerbaijan, Bahrain, Cuba, Egypt, India, Indonesia, Iraq, Kazakhstan, Laos, Malaysia, and Turkey.”).

${ }^{25}$ U.S. COMM. ON INT’L RELIGIOUS FREEDOM, 10 YeARS AFTER supra note 21 at 2.
} 
USCIRF's views binding upon the president. Rather, the statute requires only that the president "take into account any findings or recommendations by the Commission" in making CPC designations. ${ }^{26}$

Table: CPC Designations and Sanctions Action, By Country 1999-2017 $7^{27}$

[Countries designated by shading are under CPC sanction waivers]

\begin{tabular}{|l|l|l|}
\hline Country & $\begin{array}{l}\text { Years } \\
\text { Designated }\end{array}$ & Sanction Action \\
\hline Burma & $\begin{array}{l}1999- \\
\text { present }\end{array}$ & $\begin{array}{l}\text { Existing ongoing [arms embargo] restrict- } \\
\text { ions in 22 CFR 126.1 }\end{array}$ \\
\hline China & $\begin{array}{l}1999- \\
\text { present }\end{array}$ & $\begin{array}{l}\text { Existing ongoing restriction on exports to } \\
\text { China of crime control and detection instru- } \\
\text { ments and equipment, under the Foreign } \\
\text { Relations Authorization Act of 1990 and } \\
\text { 1991 (Pub. L. 101-246) }\end{array}$ \\
\hline Eritrea & $\begin{array}{l}2004- \\
\text { present }\end{array}$ & $\begin{array}{l}\text { Ongoing [arms embargo] restrictions in 22 } \\
\text { CFR 126. }\end{array}$ \\
\hline Iran ${ }^{30}$ & $\begin{array}{l}1999- \\
\text { present }\end{array}$ & $\begin{array}{l}\text { Existing ongoing travel restrictions in } \\
\text { section 221(c) of the Iran Threat Reduction } \\
\text { and Syria Human Rights Act of 2012 (TRA) } \\
\text { for individuals identified under section }\end{array}$ \\
\hline
\end{tabular}

${ }^{26}$ International Religious Freedom Act of 1998, Pub. L. No. 105-292, § 402, 112 Stat. 2787, 2802 (1998) (codified at 22 U.S.C. § 6442).

${ }^{27}$ For sanctions reporting, see Secretary of State's Determination Under the International Religious Freedom Act of 1998, 83 Fed. Reg. 1451, 1452 (Jan. 11, 2018); 81 Fed. Reg. 87997, 87997 (Dec. 6, 2016); 81 Fed. Reg. 23344, 23345 (Apr. 20, 2016); 79 Fed. Reg. 57171, 57172 (Sep. 24, 2014); 77 Fed. Reg. 20687, 20688 (Apr. 5, 2012); 74 Fed. Reg. 21843 (May 11, 2009).

28 "In 2005 the Secretary continued the designation of a sanction, consisting of a prohibition on exports or other transfers of defense articles and defense services pursuant to the Arms Export Control Act ..." 2006 Executive Summary: International Religious Freedom Report 2006, U.S. DEPT. OF STATE, https://www.state.gov/j/drl/rls/irf/2006/71284.htm [https://perma.cc/RC7A82SP] (last visited Nov. 20, 2018).

${ }^{29}$ The imposition of sanctions against Eritrea "was the first, and ... only, unique presidential action under the International Religious Freedom Act of 1998 (IRFA) in response to a CPC designation.” U.S. ComM. ON INT'L Religious FreEdom, ANN. REP. 47 (2010).

30 "The United States has no diplomatic relations with [Iran] and thus cannot raise directly the restrictions the Government places on religious freedom and other abuses that it commits against adherents of minority religions." 2005 Executive Summary: International Religious Freedom Report 2005, U.S. DEPT. OF STATE, https://www.state.gov/j/drl/rls/irf/2005/51386.htm [https:// perma.cc/3SEJ-SWAV] (last visited Nov. 20, 2018). 


\begin{tabular}{|l|l|l|}
\hline Country & $\begin{array}{l}\text { Years } \\
\text { Designated }\end{array}$ & Sanction Action \\
\hline & $\begin{array}{l}\text { 221(a)(1)(C) of the TRA in connection with } \\
\text { the commission of serious human rights } \\
\text { abuses. }\end{array}$ \\
\hline $\begin{array}{l}\text { Democratic } \\
\text { People's } \\
\text { Kepublic of }\end{array}$ & $\begin{array}{l}2003- \\
\text { present }\end{array}$ & $\begin{array}{l}\text { Existing ongoing restrictions pursuant to } \\
\text { sections 402 and 409 of the Trade Act of } \\
1974 \text { (the Jackson-Vanik Amendment) }\end{array}$ \\
\hline Saudi Arabia & $\begin{array}{l}2004- \\
\text { present }\end{array}$ & $\begin{array}{l}\text { Waiver as required in the "important nation- } \\
\text { al interest of the United States"33 }\end{array}$ \\
\hline
\end{tabular}

${ }^{31}$ The existing sanctions invoked to double-hat Iran's CPC status have varied over time. For example, in lieu of new IRFA-based sanctions against Iran, in 2012 the State Department applied "the existing ongoing restrictions on certain imports from and exports to Iran, in accordance with section 103(b) of the Comprehensive Iran Sanctions, Accountability, and Divestment Act of 2010 (Pub. L. 111-195)." Secretary of State's Determination Under the International Religious Freedom Act of 1998, 77 Fed. Reg. 20687-20688 (Apr. 5, 2012). And in 2009: "For Iran, the existing ongoing restrictions on United States security assistance in accordance with section 40 of the Arms Export Control Act ...." Secretary of State's Determination Under the International Religious Freedom Act of 1998, 74 Fed. Reg. 21843 (May. 11, 2009).

32 "The U.S. government does not have diplomatic relations with the country. The United States cosponsored resolutions at the UN General Assembly and Human Rights Council condemning the government's systematic, widespread, and gross human rights violations." U.S. Dept. of State, Democratic People’s Republic of Korea (DPRK) 2017 InTERNATIONAL RELIGIOUS FREEDOM REPORT 1 (2017).

33 The State Department has used this language since 2014. Secretary of State's Determination Under the International Religious Freedom Act of 1998, 79 Fed. Reg. 57171, 57172 (Sept. 24, 2014). The basis for the waiver has fluctuated over time. Until 2012, the Secretary invoked a "waiver "to further the purposes of the act." Secretary of State's Determination Under the International Religious Freedom Act of 1998, 77 Fed. Reg. 2068720688 (Apr. 5, 2012). In 2008, the State Department reported "because of new policies confirmed by the Saudi Arabian Government, the Secretary renewed a waiver of sanctions 'to further the purposes of the Act."' Executive Summary: International Religious Freedom Report 2008, U.S. DEPT. OF STATE, https://www.state.gov/j/drl/rls/irf/2008/108351.htm [https://perma.cc/VP6A-QQ6X] (last visited Nov. 20, 2018). Similarly, in 2006, the State Department "identif[ied] and confirm[ed] a number of key policies that the [Saudi] [g]overnment is pursuing and will continue to pursue for the purposes of promoting greater freedom for religious practice and increased tolerance for religious groups ...." In view of these developments, the Secretary issued a waiver of sanctions "to further the purposes of the Act." U.S. Dept. of State, Saudi Arabia: International Religious Freedom REPORT 200615 (2006). 


\begin{tabular}{|l|l|l|}
\hline Country & $\begin{array}{l}\text { Years } \\
\text { Designated }\end{array}$ & Sanction Action \\
\hline Sudan & $\begin{array}{l}1999- \\
\text { present }\end{array}$ & $\begin{array}{l}\text { Restriction in the annual Department of } \\
\text { State, Foreign Operations, and Related } \\
\text { Programs Appropriations Act on making } \\
\text { certain appropriated funds available for } \\
\text { assistance to the Government of Sudan, } \\
\text { currently set forth in section 7042(j) of the } \\
\text { Department of State, Foreign Operations, } \\
\text { and Related Programs Appropriations Act, } \\
\text { 2015 (Div. K, Pub. L. 114-113), and any } \\
\text { provision of law that is the same or } \\
\text { substantially the same as this provision. }\end{array}$ \\
\hline Tajikistan & $\begin{array}{l}2016- \\
\text { present }\end{array}$ & $\begin{array}{l}\text { Waiver as required in the "important } \\
\text { national interest of the United States" }\end{array}$ \\
\hline Turkmenistan & $\begin{array}{l}2014- \\
\text { present }\end{array}$ & $\begin{array}{l}\text { Waiver as required in the "important } \\
\text { national interest of the United States" }\end{array}$ \\
\hline Uzbekistan & $\begin{array}{l}2006- \\
\text { present }\end{array}$ & $\begin{array}{l}\text { Waiver as required in the "important } \\
\text { national interest of the United States"35 }\end{array}$ \\
\hline Vietnam & $\begin{array}{l}2004- \\
20066^{36}\end{array}$ & $\begin{array}{l}\text { On May 5, 2005, the United States and } \\
\text { Vietnam concluded an agreement that } \\
\text { addresses a number of important religious } \\
\text { freedom concerns. Under the agreement, }\end{array}$ \\
\hline
\end{tabular}

${ }^{34}$ Sanctions double-hatted for Sudan's CPC designation have varied slightly over time. See, e.g., Secretary of State's Determination Under the International Religious Freedom Act of 1998, 81 Fed. Reg. 23344-23345 (Apr. 20, 2016); Secretary of State's Determination Under the International Religious Freedom Act of 1998, 77 Fed. Reg. 20687-20688 (Apr. 5, 2012). In 2009, the State Department's double-hatted CPC sanction used "the voice and vote of the United States to oppose any loan or other use of the funds of international financial institutions to or for Sudan, consistent with section 1621 of the International Financial Institutions Act." Secretary of State's Determination Under the International Religious Freedom Act of 1998, 74 Fed. Reg. 21843 (May. 11, 2009).

${ }^{35}$ Previously, the State Department invoked its waiver to "further the purposes of the Act." 77 Fed. Reg. 20687-20688 (Apr. 5, 2012). See also Executive Summary, International Religious Freedom Report 2009, U.S. DEPT. OF STATE, https://www.state.gov/j/drl/rls/irf/20 09/127215.htm [https://perma.cc/LWE2-LKY4].

${ }^{36}$ In November 2006, the State Department formally removed Vietnam's CPC designation. "[O]n December 29, 2006, the United States granted Vietnam Permanent Normal Trade Relations (PNTR) status, paving the way for Vietnam to join the WTO on January 11, 2007." U.S. COMM. ON INT'L RELIGIOUS FREEDOM, 10 YeARs AfTER supra note 21 at 4. 


\begin{tabular}{|c|c|c|}
\hline Country & $\begin{array}{l}\text { Years } \\
\text { Designated }\end{array}$ & Sanction Action \\
\hline & & $\begin{array}{l}\text { Vietnam made a number of commitments } \\
\text { including: "to fully implement the new laws } \\
\text { on religious activities and to render previous } \\
\text { contradictory regulations obsolete, to instruct } \\
\text { local authorities to adhere strictly and com- } \\
\text { pletely to the new legislation and ensure their } \\
\text { compliance." This binding agreement enabled } \\
\text { Vietnam to avoid "sanctions or another "com- } \\
\text { mensurate action' associated with CPC desig- } \\
\text { nations under IRFA."37 }\end{array}$ \\
\hline Iraq $^{38}$ & 1999-2004 & CPC status removed in June $2004 .^{39}$ \\
\hline $\begin{array}{l}\text { Afghanistan/ } \\
\text { Taliban } \\
\text { Regime }\end{array}$ & $1999-2003$ & $\begin{array}{l}\text { Identified "as a matter of policy ... as a 'parti- } \\
\text { cularly severe violator' of religious freedom, } \\
\text { though it cannot be designated as a 'country of } \\
\text { particular concern' because it is not a govern- } \\
\text { ment recognized by the United States." } 40\end{array}$ \\
\hline $\begin{array}{l}\text { Serbia/ } \\
\text { Milosevic } \\
\text { Regime }\end{array}$ & $1999-2001$ & $\begin{array}{l}\text { Designated Serbia under the Milosevic } \\
\text { regime as a 'country of particular concern. }\end{array}$ \\
\hline
\end{tabular}

${ }^{37}$ Id . at 2-3. From USCIRF's perspective, "Vietnam's brief placement on the CPC list demonstrated that the pairing of the CPC designation with the binding agreement worked to foster highlevel cooperation between the United States and Vietnam, even if not to solidify lasting religious freedom improvements." Id. at 5.

38 "Prior to the fall of the Saddam Hussein regime, the United States had no diplomatic relations with Iraq and thus was unable to raise directly with the Government the problems of severe restrictions on religious freedom and other human rights abuses. However, the U.S. Government made its position clear in public statements and in diplomatic contacts with other states." Iraq: International Religious Freedom Report 2003, U.S. DEPT. OF STATE, https://www.state.gov/j/drl/ rls/irf/2003/24452.htm [https://perma.cc/3MRS-WJWY] (last visited Jan. 7, 2019).

${ }^{39}$ The 2004 IRF Report contained no Iraq chapter due to the U.S. occupation of that country. According to the State Department, "we do not report on our own governance but welcome the scrutiny of other responsible reporters. The reporting period end[ed] on June 30, which roughly coincide[d] with the date of the transfer of power from the Coalition Provisional Authority to the Iraqi Interim Government. In June, the Secretary acted to remove Iraq's designation as a 'Country of Particular Concern' for its severe violations of religious freedom under the regime of Saddam Hussein. Executive Summary: International Religious Freedom Report 2004, U.S. DEPT. OF STATE, https://www.state.gov/j/drl/rls/irf/2004/35335.htm [https://perma.cc/N6DS-XNDH] (last visited Nov. 20, 2018).

${ }^{40}$ U.S. DEP'T OF StATE, ANN. REP. ON INT’L RELigious FreEDOM 2001 xxix (2001).

41 "This designation was lifted in January 2001 after Vojislav Kostunica was elected president." Id. at xxxiii. 
Beyond USCIRF's critique that CPC designations have been too few and too static, IRFA more generally has been subject to criticism from a variety of sources and from the moment of its conception. ${ }^{42}$ As Rep. Chris Smith has described it: "frankly [IRFA] was a very tough sell. There were people in the administration and Congress who opposed it. But there was a broad coalition that came together to support the bill, bipartisan, ecumenical and inclusive of foreign policy experts that made the difference." 43

Affirming this residual opposition, President Bill Clinton attached a lengthy statement to his signature of the IRFA bill. Clinton expressed concern that the imposition of economic penalties against states violating religious freedom "could result in even greater pressures - and possibly reprisalsagainst minority religious communities that the bill is intended to help." ${ }^{, 44} \mathrm{He}$ also stressed that such measures would only be applicable in extreme situations where CPC status is triggered, and even then, the president preserved the ability to waive such action where it "would further the purpose of the Act, or if required by important national interests." $" 45$ More critically, Clinton regretted those provisions that in his view "lack[ed] this flexibility and infringe on the authority vested by the Constitution solely with the President." 46 As an example, Clinton rejected Congress' attempt to "direct . . . the president to undertake negotiations with foreign governments for specified foreign policy purposes" or to brief Congress "concerning these negotiations" as impeding the president's "constitutional responsibilities to conduct foreign affairs.",47

A consultation held soon after IRFA's passage that brought government officials, human rights professionals, representatives of religious organizations, scholars, and others together is telling of the statute's touchy origins and uncertain future. The editors of this meeting's proceedings described IRFA's congressional authors as proud of "crafting a piece of legislation that balanced

${ }^{42}$ For insight into the administration's criticisms of an early iteration of IRFA, see The International Religious Freedom Act of 1998: Before the Senate Foreign Relations Committee, 105th Cong. (1998) (statement of John Shattuck, Assistant Secretary of State for Democracy, Human Rights and Labor) (listing five main concerns, including IRFA's creation of new institutions and the requirement that the president impose executive actions or economic sanctions against violators).

${ }^{43}$ Frank R. Wolf International Religious Freedom Act of 2015; and Calling for the Release of Ukrainian Fighter Pilot Nadiya Savechenko: Markup Before the H. Subcomm. on Africa, Global Health, Global Human Rights, and International Organizations of the Committee on Foreign Affairs 114th Cong. 50 (2015).

${ }^{44}$ William J. Clinton, Statement on Signing the International Religious Freedom Act of 1998 , AM. PRESIDENCY PROJECT (Oct. 27, 1998), http://www.presidency.ucsb.edu/ws/?pid=55155.

${ }^{45} \mathrm{Id}$.

${ }^{46} I d$.

${ }^{47} I d$. 
the bully pulpit of moral exhortation with the exigencies of conducting foreign policy in a complicated world." Conversely, academic critics "took aim at the very idea of singling out religion for protection", while human rights activists "worried about the effect of the new U.S. initiative on multilateral approaches to human rights around the world." Though described as a "debate among friends," 48 over the course of the two-day conference "the veneer of politeness . . rubbed away and ... the participants were mixing it up with considerable vehemence." 49

As one manifestation of this academic critique, Johan D. van der Vyver blasted IRFA for exemplifying the United States' "sense of self-righteousness," by presuming to judge other states "while refusing to submit itself to the dictates of international law." ${ }^{50}$ Van der Vyver also questioned the flexibility IRFA provided the president for waiving action against designated CPCs on the basis of national interest: "The flexibility component . . . is also highly questionable from the perspective of the basic principles of justice in politics and in jurisprudence...Jurisprudentially, religious persecution ought not to escape punitive action....at the pleasure of the agency of enforcement."

In a similar vein, Peter Danchin criticized IRFA's creation of an "irrational hierarchy of human rights in U.S. foreign policy that makes the act vulnerable to politicization and abuse of the human rights agenda."52 Danchin further claimed IRFA "demonstrate[d] a failure of international participation and cooperation" 53 and "indirectly perpetuate[d] a strand of thinking in U.S. foreign policy that views the international order as being divided into two camps-liberal and illiberal.",54

${ }^{48}$ Center for the Study of Religion in Public Life, Trinity College; Religious PerseCution as a U.S. Policy IsSUE: ProceEdings of a CONSUltation Held AT TRINITY COLLEGE 3 (Rosalind I. J. Hackett, et al., eds., 2000).

${ }^{49} \mathrm{Id}$.

${ }^{50}$ Johan D. van der Vyver, American Exceptionalism: Human Rights, International Criminal Justice, and National Self-Righteousness, 50 EMORY L. J. 775, 827 (2001). Van der Vyer questioned IRFA's constitutionality as "entangling" the federal government in religion and presuming to apply a suspect "religious test" for appointments to USCIRF. Id. at 828.

${ }^{51} I d$. at 829. Van der Vyver concedes that IRFA "serves at least one useful purpose: the accumulation and publication of factual data on the state of religious freedom in different countries of the world." Id. at 828.

52 Peter G. Danchin, U.S. Unilateralism and the International Protection of Religious Freedom: The Multilateral Alternative, 41 Colum. J. TransNaT'L L. 33, 41 (2002).

${ }^{53} I d$. at 41 .

${ }^{54} I d$. at 42. Danchin's proposed solution for remedying violations of freedom of religion or belief is premised on a "transnational legal process whereby internal and external actors are engaged in a process of repeated interaction in such a way that the relevant norms eventually become internalized in the constitutional, legal, and political systems of all states." Id. at 135. 
Writing during the same period, other observers attempted to address and rebut these and similar critiques. For example, Jeremy Gunn, who held early positions at USCIRF and the State Department's Office of International Religious Freedom, rejected the assertion that IRFA reflected only the "political interests of the Christian Right." 55 Rather, he found "no obvious effort by the United States to favor Christians nor to seek remedies for Christian groups at the expense of other faiths." perspective, Allen D. Hertzke observed that the campaign for IRFA's passage brought together "a wide coalition of unlikely allies" moving beyond evangelical groups exclusively to include "Jewish organizations, the Episcopal Church, the Catholic Conference [of Bishops], Tibetan Buddhists, and Iranian Bahá'ís among many others." ${ }^{, 57}$ Further, because IRFA's yardstick for measuring religious freedom was grounded in international norms, Hertzke argued U.S. officials could "legitimately...claim that they are not attempting to impose 'our values' on the rest of the world. Rather, in implementing IRFA the United States is merely calling upon other nations to live up to covenants they have approved.",58

Addressing the complaint that IRFA established an improper "hierarchy of human rights. . . [with] religion freedom at its zenith,"59 Gunn countered that the legislation did not prioritize freedom of religion, but instead functioned to highlight "an important, vulnerable, and heretofore neglected right." 60 In direct response to Danchin's claim that IRFA embodied U.S. unilateralism, Gunn was even blunter:

[O]ne suspects that if the United States were not the target, Danchin and the globalists would not be so critical of unilateral action... . No country, and certainly not the United States, should be exempted from criticism. But Danchin's article

\footnotetext{
${ }^{55}$ T. Jeremy Gunn, A Preliminary Response to Criticisms of the International Religious Freedom Act of 1998, 2000 B. Y. U. L. REV. 841, 851 (2000).

${ }^{56} \mathrm{Id}$. at 855 .

${ }^{57}$ Allen D. Hertzke, International Religious Freedom Policy: Taking Stock, 2 FAITH \& INT’L AFF. 17, 19 (2008).

${ }^{58} I d$. at 18 .

${ }^{59}$ Gunn, supra note 55, at 856 . While conceding that IRFA will face an uphill struggle if it is perceived as "promoting a peculiarly American notion of religious freedom," Gunn concluded "IRFA's critics . . . frequently caricature the law and the efforts of the United States by loosely employing clichés such as 'Lone Ranger,' 'imperialism,' and 'marketoriented religion.' Such rhetorical criticisms are made without fully understanding how American diplomats actually engage other governments in discussions regarding discrimination on the basis of religion." Id. at 865 .

${ }^{60} I d$. at 857.
} 
exemplifies a real problem that sometimes occurs in the human rights community: subjecting the United States to an exceptional form of criticism that can often lead to exaggerated and distorted analysis. ${ }^{61}$

Despite the effort of Gunn and others, many of the same criticisms and misconceptions surrounding IRFA persisted or evolved over time. ${ }^{62}$ For example, writing in 2005, Eugenia Relano Pastor concluded that "While IRFA sets out to protect international religious freedom, its enforcement is undermined by the United States' other foreign policy interests, such as the war on terrorism, and a decidedly unilateral approach to the achievement of religious liberty around the globe." ${ }^{33}$ José Casanova similarly reiterated that IRFA is perceived as being "culturally insensitive or imperialistic" "the United States doesn't have a very good record in recognizing the applicability of international law to itself."

This debate persisted well into IRFA's second decade, with policymakers, academics and activists alike continuing to take sides over the merits of U.S. reporting and policing of religious freedom conditions abroad. ${ }^{66}$ For example, at a Pew Research Center forum held to commemorate ten years since IRFA's passage, John Shattuck, the Assistant Secretary of State for Democracy, Human Rights, and Labor under President Clinton, observed that four key misconceptions continued to hamper IRFA's effectives: first, the "legislation

${ }^{61}$ T. Jeremy Gunn, American Exceptionalism and Globalist Double Standards: A More Balanced Alternative, 41 COLUM. J. TRANSNAT'L L. 137, 151-52 (2002).

${ }^{62}$ Eugenia Relano Pastor, The Flawed Implementation of the International Religious Freedom Act of 1998: A European Perspective, 2005 B.Y. U. L. REV. 711, 739 (2005). Pastor takes issue with some of Gunn's rebuttals, and argues, among other things that "it is difficult, if not impossible, for IRFA not to be influenced by the American historical experience regarding freedom of religion ideas" and that actual enforcement of IRFA "inevitably yields to the United States' other foreign and domestic interests." Id. at 739, 743.

${ }^{63} \mathrm{Id}$. at 712. Observing that every CPC except for Burma successfully escaped new sanctions under IRFA, Pastor concludes that "actions taken under IRFA have been very limited, if existent at all." Id at 742. This corresponds with the evidence presented in the table above.

${ }^{64}$ José Casanova, Balancing Religious Freedom and Cultural Preservation, 2 FAITH \& INT'L AFFAIRS 13, 14 (2008).

${ }^{65} \mathrm{Id}$ at 15.

${ }^{66}$ For example, an entire volume of THE REVIEW OF FAITH \& INTERNATIONAL AFFAIRS is dedicated to contemplating IRFA at its ten-year anniversary. REV. FAITH \& INT'L AFF. (2008). Another recent critical take on IRFA presented by Elizabeth Shakman Hurd, argues the statute represents "the latest installment in a history of U.S. attempts to promote American strategic interests through social and religious engineering projects abroad." Elizabeth Shakman Hurd, Religious Freedom, American-Style, in ReLIGIOUS RigHTS 106 (Lorenzo Zucca ed., 2015). 
predominantly represents the interests of missionary religions, interested in proselytizing and changing people's religious views in other countries"; second, "the U.S. cares more about religious freedom as we define it than about other international human rights"; third, it "is based on a punitive model, in which mandatory sanctions are imposed"; and fourth, that it exemplifies U.S. unilateralism. ${ }^{67}$ Though Shattuck attempted to rebut these misconceptions, he also acknowledged that IRFA's effectiveness continued to be undermined by the inability to move beyond "naming and shaming" to the "much larger effort to connect religious freedom with the mainstream of our foreign policy. ${ }^{\prime 68}$ More practically, a 2013 report prepared for Congress by the Government Accountability Office concluded that while the State Department and USCIRF were implementing their responsibilities under IRFA, "they have not defined how they should interact, which has at times created tensions with foreigngovernment officials. ${ }^{, 69}$

Other observers build on the concern that IRFA has not been implemented effectively. For example, Thomas Farr, Former Director of the Department of State's Office of International Religious Freedom, observed that Democratic and Republican administrations as well as the State Department have failed to make promotion of religious liberty a central element of U.S. foreign policy. Instead, these actors have opted to relegate IRFA to nothing more "than a narrow humanitarian measure unrelated to broader U.S. interests." " To remedy this, Farr has argued a major change in approach is necessary: "U.S. diplomacy should move resolutely to make the defense and expansion of religious freedom a core component of U.S. foreign policy. Doing so would give the United States a powerful new tool for advancing ordered liberty and for undermining religion-based extremism at a time when other strategies have proved inadequate., ${ }^{, 1}$

Farr's emphasis relies on policymakers reorienting IRFA's priority away from opposing religious persecution and freeing religious prisoners in favor of a more "sustained discourse" that instead emphasizes the promotion

\footnotetext{
${ }^{67}$ John Shattuck, CEO, John F. Kennedy Library Foundation, Remarks at the Panel on International Religious Freedom: Religion and International Diplomacy (May 8, 2007) (transcript available at http://www.pewforum.org/2007/05/08/international-religious-freedomreligion-and-international-diplomacy [https://perma.cc/AML8-THP5]).

${ }^{68}$ Id.

${ }^{69}$ U.S. GOV'T ACCOUNTABILITY OFF., GAO-13-196, INTERNATIONAL RELIGIOUS FREEDOM Act: State Department and COMmission ARe Implementing Responsibilities but NEED TO IMPROVE INTERACTION 28 (2013).

${ }^{70}$ Thomas Farr, Diplomacy in an Age of Faith: Religious Freedom and National Security, 87 FoREIGN AFF. 110, 111 (2008).

${ }^{71} I d$.
} 
of "political order centered on religious liberty." In contrast, Hertzke has concluded that the "transformational change" necessary to cement IRFA's success must come from a "renewed commitment among religious communities to extend the freedom they enjoy in the United States to others around the globe." As evidence of the absence of this commitment, Hertzke commented in 2008: "It is telling that, in contrast to trafficking legislation pressed by the same faith-based movement, IRFA has not subsequently been amended... efforts to strengthen the law seem warranted." 72

\section{The EfFort to Amend IRFA, 2015-2016: A Legislative History on the Road to Public Law 114-281}

While IRFA did undergo several small changes since its passage in $1998,{ }^{73}$ Hertze's observation concerning the absence of a concerted effort to strengthen the law continued to hold true, at least until $2016 .^{74}$ The amendments authorized by President Obama at the end of that year represent the most significant overhaul of IRFA since its inception. Congress intended these amendments to "improve the ability of the United States to advance religious freedom globally." ${ }^{, 75}$ However, the underpinning legislative history reveals ongoing disagreements over the extent to which religious freedom should inform U.S. foreign policy. Further, this legislative history also brings into question the extent to which the United States government is prepared to commit resources to its continued policing and betterment.

This section traces the Wolf Act's legislative history to uncover the compromises and changes demanded before Congress moved to approve amendments to IRFA. Using the original House bill submitted in early 2015 as

\footnotetext{
${ }^{72}$ Hertzke, supra note 57, at 22. Among other things, Hertzke suggests "a religious freedom specialist be appointed to the National Security Council"; elevating the IRF office within the State Department; requiring "[b]roader religious training for diplomatic personnel"; and prohibiting the president from "double hatting" sanctions "to provide more teeth and bargaining leverage." Id. at 22-23.

${ }^{73}$ Until 2016, IRFA-related amendments typically tweaked statutory language or addressed reauthorization and reform of USCIRF. For example, see An Act to amend the International Religious Freedom Act of 1998, Pub. L. No. 113-154, 128 Stat. 1827 (2014) (codified at 22 U.S.C. $\S 6401$ ), and United States Commission on International Religious Freedom Reform and Reauthorization Act of 2011, Pub. L. No. 112-75, 125 Stat. 1272 (2011) (codified at 22 U.S.C. $\S 6401)$.

${ }^{74}$ In 2011, Frank Wolf, author of the original 1998 IRFA statute, introduced the International Religious Freedom Act Amendments of 2011. International Religious Freedom Act Amendments of 2011, H.R. 1846, 112th Cong. (2011). This bill included several of the amendments contained in the 2015 Wolf Act; however, it never came to a vote in Congress.

${ }^{75}$ Frank R. Wolf International Religious Freedom Act, Pub. L. No. 114-281, 130 Stat. 1426 (2016) (codified at 22 U.S.C. § 6401).
} 
a departure point, the ensuing history demonstrates that numerous provisions intended to boost IRFA's effectiveness were either diluted or altogether removed. In many cases, these changes meant abandoning sought after improvements or leaving in their place vague and open-ended provisions unlikely to achieve intended results.

\section{A. Wolf Act as Originally Introduced - February 2015}

Representative Chris Smith (R-NJ) introduced major amendments to IRFA in February 2015. According to Smith, the impetus for House Resolution 1150, the "Frank R. Wolf International Religious Freedom Act of 2015," stemmed from recognition that IRFA needed "to be updated to match the new challenges of the 21 st century... by upgrading the tools, training and resources used by the administration to advance this fundamental human right." In Smith's view, adopting H.R. 1150's proposed amendments would "better address a growing religious persecution globally and help the administration and State Department to better respond to violent extremism globally as well."76

Religious freedom advocates and human rights organizations generally supported the effort to revise IRFA. For example, the United States Conference of Catholic Bishops (USCCB) considered H.R. 1150 "an important first step in improving the [United States'] ability . . . to advance religious freedom globally. It would signify the determination of the United States to promote and protect this most fundamental of human rights."77 Similarly, the International Religious Freedom Roundtable, an umbrella group of over 30 "organizations and individuals who are scholars, religious leaders, human rights advocates and practitioners" called attention to the "deepening crisis" surrounding international religious freedom. ${ }^{78}$ This group reasoned the amendments reflected in H.R. 1150 would "send a clear and urgent message regarding the inherent dignity of every human being, as well as our common global security in the fight against persecution and religious extremism, and terrorism." 79

\footnotetext{
${ }^{76}$ Frank R. Wolf International Religious Freedom Act of 2015; and Calling for the Release of Ukrainian Fighter Pilot Nadiya Savechenko, supra note 43 at 50-51 (statement of Rep. Christopher H. Smith, Chairman, H. Subcomm. on Afr., Global Health, Global Human Rights, and Int'l Orgs).

77 H.R. Doc. No. 114-62, at 58 (2015) (providing a letter from the U.S. Conference of Catholic Bishops in support of H.R. 1150).

${ }^{78}$ Frank R. Wolf International Religious Freedom Act of 2015; and Calling for the Release of Ukrainian Fighter Pilot Nadiya Savechenko, supra note 43 at 50-51.

${ }^{79} I d$. at 59 (providing a letter from the International Religious Freedom Roundtable in support of H.R. 1150).
} 
During the bill's original markup before the House Subcommittee on Africa, Global Health, Global Human Rights, and International Organizations, Rep. Smith highlighted several specific changes his amendments to IRFA sought to achieve, including:

- Better training to "equip diplomats to counter terrorism, address anti-Semitism ... . end religious persecution and mitigate sectarian conflict";

- Enhancing the position of the Ambassador-at-Large for International Religious Freedom, by requiring direct reporting to the Secretary of State;

- Creating "a new special watch list" that would introduce a tier system for reporting on violations of freedom of religion or belief, for the purpose of putting "on notice those countries that should be or are close to being a CPC"; 80

- A reauthorization of USCIRF until $2021 ;^{81}$ and

- Enabling the president to designate non-state actors ... . "as severe violators of international religious freedom." 82

Several of these changes augured a dramatic expansion of IRFA. To justify them, Smith's draft offered new legislative findings to supplement those already underpinning IRFA. Among other things, these findings noted "growing evidence that demonstrates a connection between the absence of religious freedom and increased levels of...religiously motivated conflict, violent extremism, and terrorism, including the kind of terrorism that has reached the United States." Further, H.R. 1150 asserted it was "increasingly clear that understanding religion and the political and security implications of religious motivation and conviction is critical to the success of United States diplomacy and foreign policy initiatives." 83

On diplomatic training, IRFA originally required the Secretary of State to "establish as part of the standard training" for foreign service officers (FSOs) "instruction in the field of internationally recognized human rights." " The

${ }^{80} \mathrm{Id}$.

${ }^{81}$ United States Commission on International Religious Freedom Reauthorization Act of 2015, Pub. L. No. 114-71, § 3, 129 Stat. 563 (2015) (codified at 22 U.S.C. § 6401, 6342) reauthorized USCIRF through fiscal year 2019.

${ }^{82}$ Frank R. Wolf International Religious Freedom Act of 2015; and Calling for the Release of Ukrainian Fighter Pilot Nadiya Savechenko, supra note 43 at 51.

${ }^{83}$ Frank R. Wolf International Religious Freedom Act, H.R. 1150, 114th Cong. § 2 (2015).

${ }^{84}$ International Religious Freedom Act of 1998, Pub. L. No. 105-292, § 708, 112 Stat. 2787, 2795 (1998) (codified at 22 U.S.C. § 4028). 
statute directed that training include "instruction on international documents and United States policy in human rights" and "instruction on the internationally recognized right to freedom of religion, the nature, activities, and beliefs of different religions, and the various aspects and manifestations of violations of religious freedom." ${ }^{85}$ However, IRFA only designated as mandatory the former, and then, only for those FSO members "having reporting responsibilities relating to human rights and for chiefs of mission., 86

In practice, the extent and effectiveness of the training that emerged from the State Department testified to an ambivalent implementation which likely fell short of meaningfully connecting religious freedom to mainstream U.S. foreign policy. According to Thomas Farr, the results were disappointing: "For the past 12 years training has been ad hoc, inconsistent and ineffective." 87 A Congressionally-mandated GAO report from 2013 confirmed that the State Department had "taken steps to implement" its obligation to integrate religious freedom into its FSO training. However, its assessment betrayed an apathetic and perfunctory approach. According to the GAO's findings, since IRFA's passage, the Foreign Service Institute managed only to add "religious freedom to ... a a 90-minute session covering human rights" that is mandatory for political and economic officers and to require new FSOs to attend a mandatory 1-hour orientation session "on human rights that includes information about international religious freedom." In addition, State required "chiefs of mission to take a 2-week ambassadorial seminar, which includes a 45-minute session on global issues, including human rights." Lastly, beginning in 2011 State began piloting an optional three-day "religious freedom-specific course titled 'Religion and Foreign Policy'." This voluntary course was subsequently expanded to four days but had been offered only three times over a period of two years. ${ }^{88}$ Aside from its late introduction and non-mandatory nature, this course also drew criticism for "not focus[ing] on U.S. international religious freedom policy so much as [on] the idea of religious engagement." ${ }^{, 99}$

\footnotetext{
${ }^{85} \mathrm{Id}$.

${ }^{86}$ Id.

${ }^{87}$ Prioritizing International Religious Freedom in U.S. Foreign Policy: Hearing Before the H. Subcomm. on Africa, Global Health, and Human Rights of the H. Comm. on Foreign Affairs, 112th Cong. 42 (2011) (statement of Thomas Farr, Director, Religious Freedom Project, Berkley Center For Religion, Peace, and World Affairs, Georgetown University).

${ }^{88}$ U.S. GOV'T ACCOUNTABILITY OFF., supra note 69 at 18. Farr questioned the effectiveness of this course due to its "occasional and voluntary" nature. Prioritizing International Religious Freedom in U.S. Foreign Policy, supra note 87.

${ }^{89}$ Prioritizing International Religious Freedom in U.S. Foreign Policy, supra note 87, at 43 (statement of Mr. Thomas Farr, Director, Religious Freedom Project, Berkley Center for Religion, Peace, and World Affairs, Georgetown University).
} 
In response to this track record on training, the Wolf Act's new provision on mandatory training ${ }^{90}$ obligated the Secretary of State to carry out an elaborate religious freedom curriculum covering:

. . . the scope and strategic value of international religious freedom, how violations of international religious freedom harm fundamental United States interests, how the advancement of international religious freedom can advance such interests, how United States international religious freedom policy should be carried out in practice by United States diplomats and other Foreign Service officers, and the relevance and relationship of international religious freedom to United States defense, diplomacy, development, and public affairs efforts to combat violent extremism. ${ }^{91}$

The bill required this curriculum to be implemented within one year of enactment of the law and also made training mandatory for "all Foreign Service officers ... . including all entry level officers, all officers prior to departure for posting outside the United States, and all outgoing deputy chiefs of mission and ambassadors." ${ }^{\text {92 }}$ Further, it required such training "be shared with the United States Armed Forces, intelligence community . . . and all other Federal departments and agencies whose personnel serve as attachés, advisors, or detailees in United States embassies globally."93 The inclusion of robust and mandatory training for all FSOs signaled a win for USCIRF and others that had long advocated for such a measure. ${ }^{94}$ Its incorporation as a

${ }^{90}$ This provision borrowed from and significantly expanded upon a previously abandoned effort to amend the State Department's religious freedom training. See International Religious Freedom Acts Amendments of 2011, H.R. 1846, 112th Cong. § 103 (2011).

${ }^{91}$ Frank R. Wolf International Religious Freedom Act, H.R. 1150, 114th Cong. § 103 (2015). ${ }^{92} I d$.

${ }^{93} \mathrm{Id}$.

${ }^{94}$ Supporters in Congress had attempted to pass similar amendments to the State Department's religious freedom training previously. See International Religious Freedom Act Amendments of 2011, H.R. 1856, 112th Cong. $\$ 103$ (2011) (noting the required training for foreign service officers.); see also Prioritizing International Religious Freedom in U.S. Foreign Policy, supra note 87, at 33 (statement of Mr. Leonard Leo, USCIRF chairman) (noting "while there is some training in religious freedom for Foreign Service officers there needs to be more, and it needs to be part of the core curriculum."); HUMAN RIGHTS FIRST, HOW TO PROMOTE INTERNATIONAL RELIGIOUS FREEDOM: BLUEPRINT FOR THE NEXT ADMINISTRATION 12 (2012) (recommending, among other things, "that religious freedom and religious literacy curricula be incorporated into Foreign Service Institute (FSI) A100 courses, area-study courses, and mandatory training for all ambassadors and deputy chiefs of mission."). 
needed amendment to IRFA also reflected at least a partial remedy for the impression religious freedom was languishing as a core component of U.S. foreign policy.

To further support this training curriculum and create a more "sustained discourse" on religious freedom as a key part of U.S. foreign policy, the proposed legislation also included long-sought upgrades to the Ambassador at Large for Religious Freedom (IRF) and the Office on International Religious Freedom (OIRF). With respect to the Ambassador at Large, IRFA's original structure envisioned the IRF Ambassador to "be a principal adviser to the President and the Secretary of State." 95 However, in practice, the State Department relegated OIRF within the Bureau of Democracy, Human Rights, and Labor (DRL) (headed by an assistant secretary of state) and under the oversight of the Under Secretary for Civilian Security, Democracy, and Human Rights $(\mathrm{J}) .{ }^{96}$ This organizational structure had the effect of twice removing the Ambassador at Large from access to the Secretary of State. Moreover, it stood in contrast with other State Department Special Envoys and Special Representatives - as well as similarly situated ambassadors at large - who maintained a direct line of communication to or were housed within the Office of the Secretary of State. ${ }^{97}$ In Thomas Farr's view, this practice had deleterious effects: "When senior meetings are held on U.S. policy in China or Saudi Arabia - or even on engaging Islam - the IRF function is not considered relevant. This may seem trivial to those outside the State Department. Inside, it communicates a deadly message: IRF is not a mainstream foreign policy issue and can safely be ignored." 98

The State Department's track record of discounting the IRF ambassador did not go unnoticed by Congress. In 2011, Former Rep. Frank Wolf lamented the fact that "[o]ver successive administrations this critical position has not been treated with the seniority it deserves." 99 In response, he introduced legislation intended to repair the stature of the IRF ambassador and office. While this proposed legislative fix ultimately languished in committee, the 2015 Wolf Act as introduced revived the proposals and expanded upon

\footnotetext{
${ }^{95}$ International Religious Freedom Act of 1998, Pub. L. No. 105-292, §101, 112 Stat. 2787 (1998) (codified at 22 U.S.C. $§ 6401$ ).

${ }^{96} \mathrm{See}$ U.S. DePT. OF STATE, ORGANIZATION CHART (2016), https://www.state.gov/documents/ organization/263637.pdf.; see also U.S. DEP'T OF STATE, 1 FOREIGN AFFAIRS MANUAL 40: THE UnDER SECRETARIES OF STATE (2018) (detailing that the State Department's DRL Bureau, overseen by an assistant secretary, reports to the Under Secretary for Civilian Security, Democracy, and Human Rights).

${ }^{97}$ U.S. DEPT. OF STATE, ORGANIZATION CHART supra note 96.

${ }^{98}$ Farr, supra note 70 , at 118.

99157 CONG. REC. 854 (2011) (statement of Rep. Frank R. Wolf).
} 
them. ${ }^{100}$ Two foundational changes directed that the IRF office "shall be located in the Office of the Secretary of State" and that the IRF Ambassador "shall report directly to the Secretary of State." 101 These proposed amendments would not only have the visual effect of aligning the IRF issue with other "at large" diplomatic priorities, but would serve to erase the existing bureaucratic distance between IRF and the Secretary of State.

To reinforce these structural changes, the bill also attached sweeping new responsibilities to the IRF Ambassador's mandate and sought to elevate the influence of the office. Beyond generally advancing the right to freedom of religion abroad and recommending appropriate responses, the Ambassador would now strive more specifically to:

. . . integrate United States international religious freedom policies and religious engagement strategies into democracy, civil society, conflict prevention and mitigation, and development efforts funded by the United States and into the counterterrorism policies of Federal agencies, including the Department of Defense, the Department of Homeland Security, the Department of State, and the Department of the Treasury. ${ }^{102}$

Furthermore, the ambassador would be tasked with the new duty of coordinating "religious freedom policies and religious engagement strategies across all programs, projects, and activities of the United States." This responsibility envisioned the IRF Ambassador engaging in an open-ended manner with "any appropriate programs, projects, and activities of the Department of Defense, the Department of Homeland Security, the Department of State, the Department of the Treasury, and the United States Agency for International Development." 103

To reinforce the import attached to these new responsibilities, H.R. 1150 as introduced upgraded the IRF Ambassador's standing from "a principle advisor" to "the principle advisor" to the President and the Secretary of State on matters affecting religious freedom abroad. ${ }^{104}$ Together with this, the draft legislation also sought to strengthen OIRF. It specified that staffing would consist of "individuals to fill at least 20 full-time equivalent staff positions, and

${ }^{100}$ Compare International Religious Freedom Act Amendments of 2011, H.R. 1856, 112th Cong. §101 and Frank R. Wolf International Religious Freedom Act, H.R. 1150, 114th Cong. $\S 101(2015)$.

${ }^{101}$ H.R. 1856, $§ 101$.

${ }^{102} \mathrm{Id}$.

${ }^{103} \mathrm{Id}$.

${ }^{104} \mathrm{Id}$. 
other temporary staff positions as needed...including a senior advisor for the Office." 105 Funding for the office would be secured at a level sufficient to enable OIRF to conduct investigations "on conditions of religious freedom on a worldwide basis, and for any necessary travel to carry out the provisions of this Act." Further, the Secretary of State would provide the IRF Ambassador with "representation funds that are sufficient to carry out the duties described... at least equal to the amount of representation funds provided to other Ambassadors at Large in the Department of State."106

Related to these changes intended to secure the integration of international religious freedom matters within the decision-making echelons of the federal government, H.R. 1150 also sought to install a new Special Adviser for Global Religion Engagement and International Religious Freedom within the National Security Council (NSC). As originally enacted, IRFA contained only a "sense of Congress" provision suggesting the president appoint a Special Adviser on International Religious Freedom to serve as a resource within the NSC. ${ }^{107}$ Such "sense of" provisions "merely express the opinion of Congress or the relevant chamber. They have no formal effect on public policy and have no force of law."108 That said, they may serve as incubators for potential shifts in Congressional policy priorities or provide "an early signal that Congress will alter statutory provisions" where its informally expressed will is insufficient to effectively influence policy. ${ }^{109}$

Over IRFA's lifetime, no president ever acted to follow through with Congress' recommendation to staff the NSC with an IRF advisor. ${ }^{110}$ Faced with this inaction, H.R. 1150 moved to replace the "sense of Congress" provision with a requirement that the president appoint an NSC special advisor with more senior status and a broader set of responsibilities. Rather than sit at a director level, the new special advisor position would be "comparable to that of a senior director." 111 Similarly, rather than be tasked with generally serving

\footnotetext{
${ }^{105} I d$.

${ }^{106} \mathrm{Id}$.

${ }^{107}$ International Religious Freedom Act of 1998, Pub. L. No. 105-292, § 301, 112 Stat. 2787 (1998) (codified at 22 U.S.C. $§ 6401$ ).

108 Christopher M. DAVis, CONG. Research SERV., 98-825, “SEnSE OF” Resolutions AND PROVISIONS 1 (2016).

${ }^{109}$ Id. at 2.

110 Joseph K. Grieboski, It is Time to Prioritize Religious Freedom in U.S. Foreign Policy, HuFF. POST (Jun. 8, 2011), https://www.huffingtonpost.com/joseph-k-grieboski/it-is-time-toprioritize-_b_872758.html [https://perma.cc/PK6X-AHGB].

111 Frank $\bar{R}$. Wolf International Religious Freedom Act of 2015: Markup Before the Subcomm. on Africa, Global Health, Global Human Rights, and International Organizations of the H. Comm. on Foreign Affairs, 114th Cong. §301 (statement of Rep. Smith).
} 
as a resource for executive branch officials, making policy recommendations, and serving as liaison with the IRF Ambassador and USCIRF, the new provision defined responsibilities in concrete detail. For example, the new special advisor would assist the IRF Ambassador "to coordinate international religious freedom policies" and "develop policy recommendations and strategies relevant to the programs, projects, [and] activities" across a variety of Federal departments and agencies.

The Wolf Act as introduced also directed the NSC to establish two permanent interagency policy committees. The first, covering "International Religious Freedom and Global Religion Engagement," was to be chaired by the IRF Ambassador and tasked with developing "a strategy globally to advance international religious freedom." The second, on "Religion, International Religious Freedom, and National Security," was to be co-chaired by the IRF Ambassador and Deputy National Security Advisor, and tasked with identifying "potential national security risks related to the absence of religious freedom globally.",113

These proposed permanent committees further evidenced the desire of IRFA supporters to provide international religious freedom advocacy with a greater voice within the executive branch and deepen the IRF Ambassador's role in the policy formulation process. They also signaled an effort to push past IRFA's original vision by creating not only a figurehead presence within the NSC, but new institutionalized frameworks intended to position religion and religious freedom as central considerations in policy analysis and policy creation. ${ }^{114}$ As if to underscore the import of these proposed changes, the bill required the President to promulgate regulations implementing the new committees within 90 days. Related to this, the bill, through a nonbinding "sense of Congress" provision, called on the president's annual national security strategy report to "promote international religious freedom as a foreign policy and national security priority" and to serve as "a guide for the strategies and activities of relevant Federal agencies" as well as inform quadrennial reviews at the Department of Defense and Department of State. ${ }^{115}$

The 2015 amendments championed by Rep. Smith also sought to bring greater nuance to IRFA's CPC designation process. By introducing a formalized

\footnotetext{
${ }^{112} I d$.

${ }^{113}$ H.R. 1150, $\$ 301$.

${ }^{114}$ See International Religious Freedom Act of 1998, Pub. L. No. 105-292, § 101, 112 Stat. 2787 (1998) (codified at 22 U.S.C. § 6401) (noting Rep. Wolf's 2011 effort at amending IRFA did not put forward a similar provision for the creation of NSC committees incorporating consideration of religion and religious freedom.)

${ }^{115} \mathrm{Id}$. at $\S 703$.
} 
"Special Watch List," 116 the president could for the first time single out a country or class of countries violating religious freedom but falling short of the statutory requirements necessary to trigger CPC status. In Rep. Smith's view, this change would enable IRFA to benefit from a system already in use by the State Department as part of its mandated reporting on trafficking in persons. An added tier or level of scrutiny to IRFA's Manichean bad/other template could serve to "put on notice those countries that should be or are close to being a CPC ... so that we can begin working diplomatically to prioritize those countries."

Notably, this new intermediate designation came with a significant escalatory trigger. According to the terms of the proposed amendment, any country appearing on the Special Watch List "in more than 2 consecutive Annual [International Religious Freedom] Reports", "in any 4 Annual Reports", or "in more than 1 Annual Report [if the country had previously been designated a CPC]" would be subject to an automatic redesignation as a CPC. While this provision included executive discretion to waive the automatic CPC designation in two of the three triggering situations, it capped this ability at two years. ${ }^{118}$ More dramatically, the Special Watch List was also drafted in a manner that would make it applicable to a new category of actors subject to scrutiny under IRFA: violent nonstate actors (NSAs).

Extending IRFA's scrutiny to violent NSAs engaging in or tolerating violations of religious freedom ${ }^{119}$ signaled one of the most significant policy changes proposed by Rep. Smith's Wolf Act. Plainly, the decision to add NSAs intended to account for organizations such as ISIS and Boko Haram, ${ }^{120}$

\footnotetext{
${ }^{116}$ USCIRF has long maintained a "watch list" (now designated as Tier 2 countries) that includes countries where "religious freedom conditions do not rise to the statutory level that would mandate a CPC designation but require close monitoring due to the nature and extent of violations of religious freedom engaged in or tolerated by governments." In 2017, USCIRF's Tier 2 list consisted of: Afghanistan, Azerbaijan, Bahrain, Cuba, Egypt, India, Indonesia, Iraq, Kazakhstan, Laos, Malaysia, and Turkey. Frequently Asked Questions, USCIRF, http://www.uscirf.gov/about -uscirf/frequently-asked-questions\#FAQ\%206 [https://perma.cc/E9VF-34UA] (last visited on Dec. 20, 2018).

${ }^{117}$ Frank R. Wolf International Religious Freedom Act of 2015; and Calling for the Release of Ukrainian Fighter Pilot Nadiya Savechenko, supra note 43, at 51.

${ }^{118}$ Frank R. Wolf International Religious Freedom Act, H.R. 1150, 114th Cong. § 402 (2015). The scope of this provision appears to have been restricted to countries only: "The President may waive the application of clauses (i) or (ii) ... with respect to a country for up to 2 years ...." Id. (emphasis added).

${ }^{119}$ H.R. $1150, \S 102$.

${ }^{120}$ Frank R. Wolf International Religious Freedom Act of 2015; and Calling for the Release of Ukrainian Fighter Pilot Nadiya Savechenko, supra note 43, at 50 (statement Rep. Smith) ("We see daily headlines of beheadings, kidnappings, mob attacks, and arrests carried out by ISIS, al-Shabaab, Boko Haram and many other groups.").
} 
notorious for their religiously-motivated acts of violence targeting nonconforming Muslims and religious minorities. To justify providing IRFA with the new ability to formally scrutinize and respond to such non-state actors, H.R. 1150 proffered two key findings. First, it formally recognized ${ }^{121}$ that "religious leaders and believers are targeted by ... violent nonstate actors" $" 122$ in addition to more conventional national security forces. Second, H.R. 1150 found that such violent NSAs are an expanding force ${ }^{123}$ responsible for exposing a significant percentage of the global population to severe restrictions on freedom of religion and belief. ${ }^{124}$

With these legislative findings in place, H.R. 1150 sought to apply IRFA's existing CPC framework-including its trigger of mandatory presidential action ${ }^{125}$ - to violent NSAs. To do so, the bill set out a novel definition ${ }^{126}$ for "violent non-state actor." ${ }^{127}$ To qualify for scrutiny under IRFA, an NSA would need to be a "nonsovereign entity or group that - (A) exercises significant political power or influence at a national or international level; and (B) engages in, finances, or tolerates violations of religious freedom, terrorism, or violence or discrimination targeting religious minorities." ${ }^{\text {"28 }}$ The statute as introduced provided no guidance on the meaning to be associated with terms such as "nonsovereign" or "significant political power."

Using this definition for NSAs as a jump-off point, the bill outlined a "Statement of Policy Regarding Country of Particular Concern Designation For Violent Nonstate Actors." This statement established that U.S. policy would consider violent NSAs that have engaged in or tolerated violations of religious freedom as "eligible for designation as countries of particular concern." ${ }^{129}$ When designated as such, the full array of presidential actions - from private demarche to procurement and contract prohibitions as well as a bar on visas and admission to the United States ${ }^{130}$ _ "should be applicable to [such groups] or individual

${ }^{121}$ H.R. 1150, $§ 407$ (acknowledging that "various administrations have made [CPC] designations targeting violent nonstate actors ... such as the Taliban and Serbian groups carrying on atrocities against Bosnians").

${ }^{122} I d$. at $\S 2$.

${ }^{123} I d$. at $\S 407$.

${ }^{124} I d$. at $\S 2$.

${ }^{125} I d$. at $\S 402$ (describing "[p]residential actions in response to particularly severe violations of religious freedom").

${ }^{126}$ There is no statutory precedent for the definition. The author's conversations with individuals involved in the drafting process indicate it was crafted based on a review of academic literature.

${ }^{127}$ Frank R. Wolf International Religious Freedom Act, H.R. 1150, 114th Cong. $§ 3$ (2015).

${ }^{128} I d$.

${ }^{129} \mathrm{Id}$. at $\S 407$.

${ }^{130}$ International Religious Freedom Act of 1998, Pub. L. No. 105-292, § 405, 112 Stat. 2787, 2806-07 (1998) (codified at 22 U.S.C. § 6445). 
members of such groups." "131 Finally, to strengthen this proposed framework for dealing with violent NSAs - and to further build up the significance of USCIRF recommendations - the bill required the president to furnish Congress with reasons in the event such a group was not listed as a CPC, "particularly if [USCIRF] made a recommendation for such a designation."

A final example underscoring the effort to entrench NSA monitoring and reporting in IRFA (and to further empower USCIRF) is reflected in the bill's proposal to establish a regularly updated "Victims List." This list, to be maintained by USCIRF, was envisioned as a new tool for drawing attention to persons "imprisoned, detained, disappeared" or otherwise harmed because of their "religious activity or religious freedom advocacy." Regarding NSAs specifically, the provision allowed for including on the list those individuals subjected to harm at the hands of a foreign government or a "violent nonstate actor that the Commission recommends for designation as a country of particular concern.",133

Although the new NSA-related provisions represented a major component of the Wolf Act's amendments, it bears recalling that the original omission of nonstate actors from IRFA was not generally considered a major shortcoming of the statute. In fact, IRFA's track record suggested that both the U.S. government and USCIRF found its provisions sufficiently flexible to designate unrecognized countries and regimes as CPCs despite IRFA's original language remaining silent on making such allowances. In any case, as will be seen below, the operative definition for NSAs and IRFA's ability to police them would be subject to much debate and revision before final passage of the Wolf Act.

Beyond seeking to incorporate NSAs into IRFA's purview, the Wolf Act as introduced contained several additional amendments that merit attention. One set of these changes underscored the effort to inhibit IRFA's allowance for executive discretion. First, the act sought to tighten deadlines surrounding IRFA's reporting and designation obligations. The issue of delays and inaction on the part of the executive branch was a longstanding and recognized problem. For example, USCIRF had previously "expressed concern about the lack of any CPC designations by the Bush State Department between

\footnotetext{
${ }^{131}$ H.R. 1150, $\$ 407$.

${ }^{132} I d$. Prior to these changes, while IRFA did mandate "[a]n assessment and description of the nature and extent of violations of religious freedom in each foreign country, including ... religious persecution by ... non-governmental entities," it did not explicitly subject such entities to presidential action. International Religious Freedom Act of 1998, Pub. L. No. 105292, § 101, 112 Stat. 2787, 2787 (1998) (codified at 22 U.S.C. $§ 6401$ ).

${ }^{133}$ Frank R. Wolf International Religious Freedom Act, H.R. 1150, 114th Cong. $\S 104$ (2015).
} 
November 2006 and January 2009" as well as the failure of the Obama administration to make timely CPC designations. ${ }^{134}$ Thus, the amendments moved to replace vague language calling, for example, on the president to report and act on countries violating religious freedom "as expeditiously as practicable", with fixed deadlines of 90 days from release of the OIRF annual report. ${ }^{135}$ Similarly, the new bill required that the president undertake consultations with a country targeted with serious sanctions within 90 days rather than "as soon as practicable.",136

Second, the amendments pushed back against the president's ability to invoke an indefinite waiver on action against a designated CPC, replacing it with a maximum duration of 180 days. ${ }^{137}$ As noted above, nearly half of the currently designated CPCs are under multi-year presidential waivers that have shielded them from the imposition of any sanctions action. IRFA enabled this type of open-ended waiver because its original formulation failed to specify an expiration or time limit for presidential waivers. ${ }^{138}$ To this, the Wolf Act added a "sense of Congress" provision that explicitly condemned the presidential practice of "ongoing and persistent waivers" as not "fulfill[ing] the purposes" of IRFA. ${ }^{139}$

Expanding on the above amendments targeting executive discretion, the original Wolf Act bill moved to strengthen USCIRF in several notable ways. First, it sought to reauthorize the Commission until 2021, ${ }^{140}$ a significantly lengthier period than afforded by prior Congressional reauthorizations. This push to secure an extended future for the bipartisan watchdog can be traced to Rep. Frank Wolf's view that USCIRF, "unlike the State Department, is unencumbered by the impulse to maintain good bilateral relations above all else - an impulse which sadly can result in critical issues of religious freedom being sidelined in the pursuit of broader foreign policy goals." 141 From this vantage point, protecting USCIRF's mandate would ensure that the State Department's ability to conduct foreign policy would continue to be "irritated" by IRFA's demand - as personified by the Comm-

\footnotetext{
${ }^{134}$ U.S. COMM’N ON INT'L RELIGIOUS FrEEDOM, ANNUAL REPORT 7-8 (2010).

${ }^{135}$ H.R. 1150, § 401-402.

${ }^{136} \mathrm{Id}$. at $\S 403$.

${ }^{137}$ Compare $\S 407$ with $\S 405$ of the International Religious Freedom Act of 1998, Pub. L. No. 105-292, 112 Stat. 2787, 2787 (1998) (codified at 22 U.S.C. § 6445, 6647) (requiring the president to take action within 180 days at the maximum).

138 International Religious Freedom Act of 1998, Pub. L. No. 105-292, §407(a), 112 Stat. 2787, 2787 (1998) (codified at 22 U.S.C. § 6401).

${ }^{139}$ Frank R. Wolf International Religious Freedom Act, H.R. 1150, 114th Cong. $\S 405$ (2015).

${ }^{140} \mathrm{Id}$. at $\S 205$.

${ }^{141} 157$ CONG. REC. 854 (2011) (statement of Rep. Frank R. Wolf).
} 
ission - that religious freedom considerations inform the formulation and execution of that policy. ${ }^{142}$ Second, as if to drive home USCIRF's role in constraining executive discretion, the Wolf Act also mandated that the president furnish an explanation in the event the executive branch ignored a USCIRF recommendation to designate a particular country as a CPC. ${ }^{143}$

The final pair of original Wolf Act amendments worth noting signaled efforts to expand IRFA's ability to sanction individuals for violations of religious freedom and to guarantee funding levels for religious freedomrelated activities. As noted above, IRFA's original design provided for the imposition of sanctions against target countries for violations of religious freedom. But it also amended the Immigration and Nationality Act to require the State Department to deny entry to individual foreign government officials who were "responsible for or directly carried out . . . particularly severe violations of religious freedom."144 The Wolf Act as introduced sought to enlarge this latter ability to penalize individuals. Under Section 605, the proposed bill enabled the president to sanction individuals responsible for engaging in or tolerating particularly severe violations of religious freedom. This power, premised on the International Emergency Economic Powers Act, would be broadly applicable to any foreign person determined by the President to play "a role in committing, ordering, sponsoring, or materially

${ }^{142}$ According to Rep. Smith, "Religious freedom has always been orphaned within the State Department . . . usually the Foreign Service officer tasked with religious freedom issues is someone very, very low on the totem poll and the Ambassador, the DCM [Deputy Chief of Mission] and others see it as an irritant." Prioritizing International Religious Freedom in U.S. Foreign Policy, supra note 87, at 25. This view is corroborated by Thomas Farr: "the State Department views the Commission as an irritant. That it does not pay more than just lip service to many of its recommendations over the years ...." Id. at 80.

${ }^{143}$ H.R. 1150, $\$ 402$.

${ }^{144}$ International Religious Freedom Act of 1998, Pub. L. No. 105-292, §604(a), 112 Stat. 2787, 2814 (1998) (codified at 22 U.S.C. § 6473(a)). In 2005, Narendra Modi, India's current prime minister, became the first individual to be denied an entry visa under this provision of IRFA. The State Department denied Modi's visa based on riots that occurred in 2002 during his tenure as head of Gujarat state and resulted in the death of over 1,000 Muslims. For coverage of this event, see Zahir Janmohamed, U.S. Evangelicals, Indian Expats Teamed Up to Push Through Modi Visa Ban, N.Y. TIMEs (Dec. 5, 2013), https://india.blogs.nytimes.com /2013/12/05/u-s-evangelicals-indian-expats-teamed-up-to-push-through-modi-visa-ban/; James Mann, Why Narendra Modi Was Banned From the U.S., Wall ST. J. (May 2, 2014, 4:26 PM), https://www.wsj.com/articles/why-narendra-modi-was-banned-from-the-u-s-1399062 010. USCIRF renewed its call to deny Modi entry to the United States again in 2008, when he planned to participate in a conference celebrating Gujarati culture. Press Release, USCIRF, USCIRF Urges Denial of U.S. Visa to Gujarat Chief Minister Narendra Modi (Jul. 8, 2008), http://www.uscirf.gov/news-room/press-releases/uscirf-urges-denial-us-visa-gujarat-chiefminister-narendra-modi [https://perma.cc/67WH-5CVW]. 
supporting systemic, egregious, and ongoing violations of religious freedom" or who provides "material or other assistance supporting violence or terrorist acts targeting members of religious groups." "145 Further, it would enable the president to take a larger range of actions beyond denial of entry, including prohibiting financial transfers, and the acquisition, holding, or use of any property by a foreign national. ${ }^{146}$

Finally, to undergird its effort to revitalize IRFA and place religious freedom at the center of U.S. foreign policy, the Wolf Act assigned explicit funding to the mission of promoting freedom of religion. Originally, IRFA merely amended the Foreign Assistance Act of 1961 provision authorizing the president to use allocated funds to carry out "programs and activities which will encourage or promote increased adherence to civil and political rights" to include a reference to "the right to free religious belief and practice." ${ }^{.147}$ Under the changes proposed, "not less than 10 percent" of the amounts made available for 2016-2021 for the Human Rights and Democracy Fund (HRDF) would be designated for the specific "promotion of international religious freedom."148 This funding would be used for grants to groups pursuing legal protections for religious freedom; the promotion of cultural and societal understanding of international religious freedom norms; the reduction of religiously motivated and sectarian violence and extremism; and the reporting and monitoring of religious freedom violations. ${ }^{149}$ Further, an additional minimum two percent of HRDF money would be earmarked for a new fund dedicated to boosting religious freedom. The Religious Freedom Defense Fund, situated within the State Department and administered by the IRF Ambassador, would enable the issuing of grants to:

${ }^{145}$ Frank R. Wolf International Religious Freedom Act, H.R. 1150, 114th Cong. § 601 (Actions against persons responsible for committing particularly severe violations of international religious freedom) (as introduced in House, Feb. 27, 2015).

${ }^{146}$ International Emergency Economic Powers Act, Pub. L. 95-223, § 203, 91 Stat. 1625, 1626-1627 (1977).

14722 U.S.C. $§ 2151(n)(e)$ (1999) (encouraging the president to use allocated funds "for studies to identify, and for openly carrying out programs and activities which will encourage or promote increased adherence to civil and political rights, including the right to free religious belief and practice, as set forth in the Universal Declaration of Human Rights").

${ }^{148}$ DRL Programs, U.S. DEP'T OF STATE, https://www.state.gov/j/drl/p/ [https://perma.cc/ 9XT7-9JF6] (last visited Dec. 31, 2018) ("The Human Rights and Democracy Fund (HRDF), established by Congress in 1998, functions as a 'venture capital fund' for democracy and human rights, enabling State to respond quickly and flexibly to changing needs and opportunities to advance democracy and promote human rights."). See also Human Rights and Democracy Fund, 22 U.S.C $§ 2151(n)(2)$.

${ }^{149}$ H.R. 1150, $\S 501$ (as introduced in House, Feb. 27, 2015). 
- Victims of religious freedom abuses and their families to cover legal and other expenses that may arise from detention, imprisonment, torture, fines, and other restrictions; and

- Projects to help create and support training of a new generation of defenders of religious freedom, including legal and political advocates, and civil society... ${ }^{150}$

Despite Rep. Smith touting the Wolf Act's "strong bipartisan support," ${ }^{151}$ even at this early stage in the lawmaking process rumblings of opposition were apparent. Two months after its introduction, during subcommittee markup for the bill, Rep. David Cicilline (D-RI) communicated concerns expressed by the Obama administration regarding the Wolf Act's proposed "changes to internal State Department structure," "potential drains on democracy funding of other important programs," and its reauthorization of USCIRF "without important reforms." "152 Rep. Cicilline's expressed hope that these differences could be addressed "as this legislation moves forward" would set expectations for the next round of House negotiations. ${ }^{153}$

\section{B. Engrossed in House - May 2016}

If the attempt to extend IRFA's mandate to NSA activity reflected one of the Wolf Act's biggest innovations, precisely how this scrutiny would play out was subject to the biggest modifications before the full House extended its endorsement to the bill over a year later. First, the revised bill deleted the finding that 75 percent of the global population lives in countries where either the government or violent nonstate actors severely restrict the right to the freedom of religion and belief. More significantly, it overhauled the definition for nonstate actor to dramatically narrow the range of NSAs that could fall under IRFA scrutiny. Instead of using the ambiguous term "nonsovereign entity" the bill required that the NSA "not belong to or ally itself to any particular country." 154 Further, it required that an NSA exercise significant

${ }^{150} \mathrm{Id}$.

${ }^{151}$ H.R. Rep. No. 114-62 (2015) (Comm. Markup) (according to Rep. Smith: "Some 10 Democrats have signed on as cosponsors of the bill, and the lead cosponsor of the bill is Anna Eshoo ... We have 80 total sponsors of the bill and the number is growing by the day.")

${ }_{152} I d$.

${ }^{153} I d$.

${ }^{154}$ Frank R. Wolf International Religious Freedom Act, H.R. 1150, 114th Cong. § 3 (definitions) (as engrossed in House, May 16, 2016) (noting House suspended rules and passed bill by voice vote). 
political power and (rather than "or") the ability to exert influence. Finally, the new version required that an NSA "often employ[] illegal violence in pursuit of its objectives." "155 These changes effectively rejected the original bill's more flexible, if vague, language capturing a wider swath of NSAs based on "financ[ing] or tolerat[ing] violations of religious freedom ... or discrimination targeting religious minorities." 156 In other words, under the new formulation, NSAs aiding or tolerating violations or discrimination impacting freedom of religion or belief but otherwise avoiding violence would no longer be subject to scrutiny under IRFA. Further, even if an NSA met the higher "illegal violence" criteria, it would still need to satisfy the definitional tests concerning "significant political power," national or international influence, and independence to fall under IRFA.

Beyond narrowing the operative definition of NSAs that would trigger IRFA scrutiny, the revised bill also deleted the entire "Statement of Policy Regarding Country of Particular Concern Designation For Violent Nonstate Actors." In doing so, the bill undid the requirement for mandatory presidential action where an NSA was found to have "engaged in or tolerated violations of religious freedom." ${ }^{157}$ Whereas the original House bill required the president to act using the full range of sanctions available under IRFA, the revised bill introduced two significant changes. First, it premised presidential action on a higher threshold, paralleling the standard applicable to CPCs. Accordingly, before executive action could be directed against an NSA, it would have to be found to "have engaged in particularly severe violations of religious freedom"158 and designated an "Entity of Particular Concern" (EPC) ${ }^{159}$ by the president.

\footnotetext{
${ }^{155} \mathrm{Id}$.

${ }^{156}$ Frank R. Wolf International Religious Freedom Act, H.R. 1150, 114th Cong. $\$ 3$ (definitions) (as introduced in House, Feb. 27, 2015).

${ }^{157} \mathrm{Id}$. at $\S 401$ (Presidential actions in response to violations of religious freedom).

${ }^{158}$ H.R. 1150, $\S 301$ (Non-State Actor Designations) (as engrossed in House, May 16, 2016).

${ }^{159} \mathrm{Id}$. This is not the first time the term "entities of particular concern" would appear in IRFA. The original law employs the term in connection with the requirement to publish IRFA determinations in the Federal Register. Under the heading "Determinations of Governments, Officials, and Entities of Particular Concern," the president is obligated to publish in the Federal Register "[a]ny designation of a country of particular concern for religious freedom ... together with, when applicable and to the extent practicable, the identities of the officials or entities determined to be responsible for the violations." International Religious Freedom Act of 1998, Pub. L. No. 105-292, §408(a)(1), 112 Stat. 2787, 2808 (1998) (codified at 22 U.S.C. $\S$ 6448). An EPC designation under the House-revised bill maintains a parallel presidential obligation to "seek to determine the specific officials or members thereof that are responsible for the particularly severe violations of religious freedom.” H.R. 1150, $\S 301$ (Non-State Actor Designations) (as engrossed in House, May 16, 2016).
} 
At the same time, the revised bill retreated from mandating the president to take statutorily-defined action. Instead, it merely suggested that the "President should take specific actions to address severe violations of religious freedom" by EPCs, "including taking actions commensurate to" those already designated under IRFA. ${ }^{160}$ Thus, while the revised bill signaled a laudable effort to integrate a new EPC designation alongside the preexisting CPC regime, it left the actual post-designation treatment of EPCs adrift. Rather than transpose CPC provisions governing mandatory action based on a preset menu of options, the bill discarded requirements for such action as well as the need to do so within a fixed timeframe.

Perhaps to compensate for discarding deadlines and mandatory action against NSAs, the House-revised Wolf Act added a new "sense of Congress" provision recommending the Secretary of State work with Congress to "create new political, financial, and diplomatic tools to address severe violations of religious freedom by non-state actors" and to "update the actions the President can take" under these EPC scenarios in IRFA. ${ }^{161}$ It also newly required the President furnish Congress with a "report detailing the reasons"162 for any EPC designation, that the Annual IRF Report's executive summary include any country within which an EPC is located, ${ }^{163}$ and further, that any designation of an EPC be published in the Federal Register. ${ }^{164}$

The downgraded emphasis on addressing NSAs violating religious freedom is similarly evident in revisions to the Special Watch List proposal. The Watch List was originally conceived to establish a new tier system under IRFA for reporting on religious freedom violations. The House-approved bill, however, rejected inclusion of NSAs on the Watch List. Thus, it signaled that only countries tolerating serious violations of religious freedom falling short of the CPC standard would be eligible for inclusion on the list. ${ }^{165}$ In addition to scrapping the possibility of using this tool to place NSAs on notice for religious

\footnotetext{
${ }^{160}$ H.R. 1150, $\$ 301$ (Non-state Actor Designations) (as engrossed in House, May 16, 2016) (emphasis added).

${ }^{161}$ Id.

${ }^{162} \mathrm{Id}$.

${ }^{163} I d$. at $\S 102$ (Annual Report on International Religious Freedom).

${ }^{164} \mathrm{Id}$. at $\S 305$. The Federal Register published the first set of EPC designations in March 2018. Secretary of State's Determination Under the Frank R. Wolf International Religious Freedom Act of 2016, 83 Fed. Reg. 10545 (Mar. 8, 2018) (designating as EPCs the following NSAs: al-Nusra Front, al-Qa'ida in the Arabian Peninsula, al-Qa'ida, al-Shabab, Boko Haram, ISIS, ISIS-Khorasan, and the Taliban).

${ }^{165}$ Frank R. Wolf International Religious Freedom Act, H.R. 1150, 114th Cong. § 102 (Annual Report on International Religious Freedom) (as engrossed in House, May 16, 2016).
} 
freedom violations falling short of the "particularly severe" standard, deleting NSAs from the watch-list also meant that such entities would no longer be subject to automatic EPC status if they appeared on the list in more than two consecutive IRF annual reports. ${ }^{166}$ Additional amendments impacting the Watch List provision also resulted in limiting an automatic CPC designation only to those countries appearing on the list in "more than two consecutive Annual Reports." 167

One exception to the revised bill's rollback of provisions targeting NSAs can be seen in the decision to retain the proposal to create and maintain a list of victims harmed for their religious activity or religious freedom advocacy. By preserving this provision, the House saved USCIRF's new mandate to report on individuals detained, disappeared or otherwise targeted by a "non-state actor that the Commission recommends for designation as an entity of particular concern for religious freedom." ${ }^{, 168}$ Still, USCIRF would need to show that any listed NSA satisfied the more rigorous EPC standard established under the House version before it could add any impacted individual to the victims list.

Additional modifications that occurred at this stage of the legislative process are equally significant because they signal a wider downgrading of the tenor and thrust of the IRFA amendments as originally proposed. For example, the bill approved by the House deleted major enhancements intended to boost the status and function of the Ambassador at Large for Religious Freedom (IRF) and the Office on International Religious Freedom (OIRF). Although the Houseapproved bill opted to preserve the IRF Ambassador's new direct reporting line to the Secretary of State, it discarded the relocation requirement, preferring to keep OIRF within the State Department's Bureau of Democracy, Human Rights, and Labor. In place of this relocation, the engrossed bill substituted a nonbinding "sense of Congress" provision calling on the Secretary of State merely to "consider elevating" OIRF and the IRF Ambassador "to the Office of the Secretary, similar to other Ambassador-at-Large positions that now report

${ }^{166} I d$. at $\S 302$ (listing presidential actions in response to particularly severe violations of religious freedom).

${ }_{167}^{167}$.

${ }^{168} I d$. at $§ 104$ (including prisoner lists and issue briefs on religious freedom concerns). Although the House-revised bill retained the new prisoner list provision, it simultaneously discarded the original bill's attempt to make it "be the policy of the United States Government"- rather than IRFA's existing "sense of Congress" - that "all officials ... shall promote" increased advocacy on such issues during meetings with foreign dignitaries. Compare Frank R. Wolf International Religious Freedom Act, H.R. 1150, 114th Cong. § 104 (providing prisoner lists and issue briefs on religious freedom concerns), as Introduced in House, Feb. 27, 2015 and Frank R. Wolf International Religious Freedom Act, H.R. 1150, 114th Cong. § 104 (including prisoner lists and issue briefs on religious freedom concerns), as Engrossed in House, May 16, 2016. 
directly to the Secretary." 169 Equally revealing, the bill deleted the provision that would have elevated the ambassador's status to "the principal advisor" to the president regarding matters affecting religious freedom abroad, permitting this jump in status only with respect to advising the Secretary of State. ${ }^{170}$

Coupled with the decision to eschew upgrading the organizational status of OIRF and the IRF Ambassador, the House-approved bill also clawed back the ambassador's new responsibilities for integrating IRF policy. Instead of robust and defined duties extending into the work of various federal departments and agencies, the House-approved version called generally for "integrat[ing] United States international religious freedom policies and strategies into the foreign policy efforts of the United States." ${ }^{171}$ While this change might appear cosmetic in nature, the lack of specificity may make future integration efforts more difficult and subject to administrative impediments. Perhaps as a token to soften these blows, the House-approved bill promised to enlarge OIRF staffing from the originally proposed 20 to 25 full-time staff. Still, this change came at the expense of deleting the requirement that OIRF include a senior director and downgrading the language on representation funds from "levels at least equal to" to "in amounts comparable to those provided to other Ambassadors."

Further illustrating the overall downgrading of the proposed IRFA amendments, the House-approved bill rejected provisions intended to boost religious freedom advocacy within the National Security Council (NSC). First, the House scrapped the requirement that the president appoint a "Special Adviser for Global Religion Engagement and International Religious Freedom" to the NSC. ${ }^{173}$ In place of mandating this appointment, the House-approved bill simply

169 H.R. 1150, $\S 101$ (Office on International Religious Freedom; Ambassador at Large for International Religious Freedom) (as engrossed in House, May 16, 2016). For example, see Bureaus/Offices Reporting Directly to the Secretary, U.S. DEP'T OF STATE, https://www.state. gov/s/index.htm [https://perma.cc/G29P-AHGA] (last visited Dec. 31, 2018) and Special Envoys, Representatives, Coordinators, AM. FOREIGN SERVICE ASS'N, http://www.afsa.org/specialenvoys-representatives-and-coordinators [https://perma.cc/N27N-U33K] (last visited Nov. 20, 2018). Note that the number of these special representatives is poised to drop. Colum Lynch \& Robbie Gramer, State Department Reorganization Eliminates Climate, Muslim and Syria Envoys, FOR. POL. (Aug. 29, 2017), https://foreignpolicy.com/2017/08/29/state-department-reorgani zation-eliminates-climate-muslim-and-syria-envoys/ [https://perma.cc/GFW4-YJ65].

${ }^{170}$ H.R. 1150, § 101 (Office on International Religious Freedom; Ambassador at Large for International Religious Freedom) (as engrossed in House, May 16, 2016).

${ }^{171}$ Id.

${ }^{172}$ Compare with H.R. 1150, $\$ 101$ (Office on International Religious Freedom; Ambassador at Large for International Religious Freedom) (as engrossed in House, May 16, 2016).

${ }^{173}$ H.R. 1150, § 301 (Special Adviser for Global Religion Engagement and International Religious Freedom; Interagency Policy Committees) (as introduced in House, Feb. 27, 2015) (noting 
reverted to IRFA's original "sense of Congress" formulation recommending appointment of a "Special Adviser to the President on International Religious Freedom." At the same time, it expanded slightly on IRFA's originally envisioned role for the NSC adviser by, for example, suggesting the position include assisting the IRF Ambassador "to coordinate international religious freedom policies and strategies throughout the executive branch."174

Second, the House-approved bill also discarded the provision that sought to establish two new NSC-based interagency policy committees-one on "International Religious Freedom and Global Religion Engagement" and another on "Religion, International Religious Freedom, and National Security." Taken together, these revisions effectively ended efforts to secure a reinvigorated role for religious freedom within the NSC. At the same time, they served to diminish the elevated status afforded to the IRF Ambassador under the original bill. ${ }^{175}$ As if to cement the rejection of a more central policy-making role for the IRF Ambassador within the NSC, the House's revised bill tepidly added (as part of the mandate holder's new coordination duties) that the ambassador "should participate in any interagency processes on issues in which the promotion of international religious freedom policy can advance United States national security interests, including in democracy promotion, stability, security, and development globally."

The House approved bill also undid efforts to enhance IRFA's sanctioning ability and to secure financing to promote religious freedom. In place of the original bill's explicit grant of authority to sanction individuals violating religious freedom, the House directed the Secretary of State simply to establish and maintain a "Designated Persons List" of foreign individuals who are sanctioned, through visa denials, financial sanctions, or other measures, because

that the special adviser would "coordinate international religious freedom policies and global religion engagement strategies . . . and develop policy recommendations.”).

${ }^{174}$ Compare International Religious Freedom Act of 1998, Pub. L. No. 105-292, § 301, 112 Stat. 2787, 2800 (1998) (codified at 22 U.S.C. § 6436) (Special Adviser on International Religious Freedom) with Frank R. Wolf International Religious Freedom Act, H.R. 1150, 114th Cong. $\S 201$ (Special Adviser for International Religious Freedom) (as engrossed in House, May 16, 2016).

175 Frank R. Wolf International Religious Freedom Act, H.R. 1150, 114th Cong § 301 (Special Adviser for Global Religion Engagement and International Religious Freedom; Interagency Policy Committees) (as introduced in House, Feb. 27, 2015). The original bill tasked the former committee (chaired by the IRF Ambassador) with developing "a global strategy to advance international religious freedom", and the latter committee (co-chaired by the IRF Ambassador and Deputy National Security Advisor) with identifying "potential national security risks related to the absence of religious freedom globally." Id.

${ }^{176}$ H.R. 1150, § 101 (Office on International Religious Freedom; Ambassador at Large for International Religious Freedom) (as engrossed in House, May 16, 2016). 
of their responsibility for "ordering, controlling, or otherwise directing particularly severe violations of freedom [sic] religion."177 As part of this obligation, the Secretary would provide Congress with regular updates to the list, including a "description of the actions taken ... in response to" those individual included therein. ${ }^{178}$ In this case, negotiation and passage of the Global Magnitsky Human Rights Accountability Act provides a likely explanation for the decision to delete the express ability to impose sanctions on individual government officials for violations of religious freedom under IRFA. ${ }^{179}$

Coupled with this, the House retreated from mandating minimum funding for the protection and advancement of international religious freedom through the State Department's Human Rights and Democracy Fund and the Religious Freedom Defense Fund. Rather than preserve the State Department's obligation to fund religious freedom promotion activities at guaranteed levels, the approved bill opted instead to express a nonbinding "sense of Congress" that funding ought to be pegged at such levels. ${ }^{180}$

Finally, the House took aim at provisions intended to fortify USCIRF and to reduce executive discretion. In the first instance, it discarded all provisions of the original H.R. 1150 bill directed at reforming USCIRF, including its reauthorization until 2021. ${ }^{181}$ At the same time, it further undercut the Commission's stature (and the effort to reign in executive discretion) by deleting the proposal requiring the president to explain any decision to forgo a CPC designation where USCIRF had made a prior recommendation supporting such a designation. ${ }^{182}$ Similarly, the House approved bill rejected at least some

${ }^{177} I d$. at $\S 501$ (Designated Persons List for Particularly Severe Violations of Religious Freedom).

${ }^{178} I d$.

${ }^{179}$ The Global Magnitsky Human Rights Accountability Act enables the president to impose sanctions "based on credible evidence" that a foreign person is "responsible for extrajudicial killings, torture, or other gross violations of internationally recognized human rights committed against individuals in any foreign country who seek . . . to obtain, exercise, defend, or promote internationally recognized human rights and freedoms, such as the freedoms of religion ..." Global Magnitsky Human Rights Accountability Act, Pub. L. 114328, § 1263, 130 Stat. 2533 (2016) (codified at 23 U.S.C. § 2656) (Authorization of Imposition of Sanctions).

${ }^{180}$ Frank R. Wolf International Religious Freedom Act, H.R. 1150, 114th Cong. § 401 (Assistance for Promoting Religious Freedom) (as engrossed in House, May 16, 2016).

${ }^{181}$ The House approved version of H.R. 1150 entirely deleted Title II of the bill as introduced, the section that addressed reform and reauthorization of the Commission.

${ }^{182}$ Frank R. Wolf International Religious Freedom Act of 2015, H.R. 1150, 114th Cong. $\S 402$ (Presidential actions in response to particularly severe violations of religious freedom) (as introduced in House, Feb. 27, 2015). As noted, this obligation to explain non-designation would represent a check on executive discretion. 
of the amendments proposed in 2015 that intended to impose stricter deadlines for action and limits on the duration of presidential waivers. For example, the new bill eliminated amendments imposing 90-day deadlines for the president to act in response to countries violating religious freedom (though not in a particularly severe manner) and to engage in consultations with those countries subject to such action under section 401 of IRFA. Perhaps more significantly, rather than endorse the suggested 180-day limit on such CPC waivers, ${ }^{183}$ the new bill restored the president's authority to seek an indefinite waiver after expiry of an initial 180-day waiver period. The president could activate this second waiver "for any additional period of time after the 180-day period" by providing a determination that the "respective foreign government has ceased the [relevant] violations" or "the exercise of such authority is important to the national interests of the United States." ${ }^{184}$ Perhaps to offset the return of an indefinite waiver, the approved House bill preserved a "sense of Congress" provision asserting that "ongoing and persistent waivers of the application of [sanction actions under IRFA $\S 405$ (a) 9 9-15] do not fulfill the purposes of this Act", and reasoning that "because the promotion of religious freedom is a compelling interest of United States foreign policy, the President [and others] should seek to find ways to address existing violations, on a case-by-case basis, through the actions specified in [IRFA $\S 405]$." 185

From the analysis above, the House-approved version of the Wolf Act resulted in significant revisions to diminish the scrutiny of NSAs and undo other major efforts to boost IRFA's effectiveness and centrality in U.S. foreign policy. Still, it retained some positive amendments and introduced at least one critical improvement. First, the bill preserved most of the provisions setting out new mandatory training requirements for the State Department. It did opt to downgrade the obligation to share training materials with a detailed list of federal departments and agencies in favor of a suggestion the materials should be made available to all other Federal agencies. However, the only other changes to this amendment related to minor revisions to language. Second, the House-approved bill preserved some of the efforts to hold the president to a more defined time table with respect to reporting on CPCs. For example, it preserved the call for 90-day time limits on presidential review and determination of CPCs and on reporting to Congress action flowing from

\footnotetext{
${ }^{183}$ H.R. 1150, $§ 405$ (Presidential Waiver) (as introduced in House, Feb. 27, 2015)

${ }^{184}$ H.R. 1150, $\$ 304$ (Presidential Waiver) (as engrossed in House, May 16, 2016).

${ }^{185}$ Compare H.R. 1150, $\S 405$ (Presidential Waiver) (as introduced in House, Feb. 27, 2015) with International Religious Freedom Act of 1998, H.R. 1150, 114th Cong. \$304 (Presidential Waiver) (as engrossed in House, May 16, 2016).
} 
such designations. ${ }^{186}$ Third, the House maintained the "sense of Congress" provision calling on the president's annual national security strategy report to "promote international religious freedom as a foreign policy and national security priority." 187 Finally, the House-approved bill also endorsed the new Victims List amendment, making only slight changes to accommodate the shift away from violent NSAs to the newly introduced EPC system.

Perhaps the most notable improvement to the original bill related to a revision of IRFA's definition of the right to freedom of thought, conscience and religion. The edits introduced in the House-approved bill expressly recognized that this right includes protection of "theistic and non-theistic beliefs as well as the right not to profess or practice any religion." ${ }^{\text {"188 }}$ This finding is further strengthened elsewhere in the bill by acknowledging that "the specific targeting of non-theists, humanists, and atheists ... [is often particularly widespread, systematic, and heinous] . . . in regions where nonstate actors exercise significant political power and influence." ${ }^{, 189}$ Incorporating this revision represented no small achievement. According to the American Humanist Association, the four-year effort to "include inclusive language protecting non-believers," signaled "a significant step toward full acceptance and inclusion for non-religious individuals." $" 190$ The move also served to bring IRFA more closely into line with the international understanding of the scope of freedom of religion or belief. According to the UN Human Rights Committee, the right to freedom of thought, conscience and religion "protects theistic, non- theistic and atheistic beliefs, as well as the right not to profess any religion or belief. The terms "belief" and "religion" are to be

\footnotetext{
${ }^{186}$ See Frank R. Wolf International Religious Freedom Act of 2015, H.R. 1150, 114th Cong. $\S 402$ (Presidential actions in response to particularly severe violations of religious freedom) (as introduced in House, Feb. 27, 2015); see also Frank R. Wolf International Religious Freedom Act, H.R. $1150,114^{\text {th }}$ Cong. $\$ 302$ (Presidential actions in response to particularly severe violations of religious freedom) (as engrossed in House, May 16, 2016). The original version of IRFA offered little in the way of clear deadlines, appearing to provide the president with a year to review country status and make determinations, and similarly, requiring only that the president notify congress "as soon as practicable after the designation is made." H.R. $1150, \S 402$ (b) (Presidential actions in response to particularly severe violations of religious freedom) (as introduced in House, Feb. 27, 2015.

${ }^{187}$ H.R. $1150, \S 703$ (Sense of congress regarding national security strategy to promote religious freedom through United States foreign policy) (as engrossed in House, May 16, 2016).

${ }^{188}$ H.R. 1150, § 2 (Findings; Policy) (as engrossed in House, May 16, 2016).

${ }^{189} I d$.

${ }^{190}$ Obama Signs Modified Religious Freedom Law, AMS. UnITED FOR SEPARATION OF CHURCH \& STATE (Feb. 2017), https://www.au.org/church-state/february-2017-church-state/au-bulletin/ obama-signs-modified-religious-freedom-law [https://perma.cc/ST4L-HR5A].
} 
broadly construed."191 Among other things, this means that the freedom to "have or to adopt" a religion or belief "necessarily entails the freedom to choose a religion or belief, including the right to replace one's current religion or belief with another or to adopt atheistic views."192

\section{Senate Revisions - December 2016}

After gaining the House's approval, the Wolf Act proceeded to deliberations in the Senate. These negotiations, ultimately leading to a version of the bill approved in December 2016, brought about further revisions to the House approved text discussed above. Here again, much of the focus for changes revolved around how to implement the new system for monitoring NSA-based violations of religious freedom. On one hand, the Senate preserved the review, designation and reporting regime ${ }^{193}$ for EPCs, the inclusion of EPCs in the IRF annual report executive summary, ${ }^{194}$ and the provisions relating to USCIRF preparing and maintaining a list of victims of EPCs. ${ }^{195} \mathrm{On}$ the other hand, despite these carryovers, the Senate took steps to further limit the potential impact of IRFA's new NSA-related provisions.

For example, the Senate moved to further narrow the Wolf Act's operative definition for NSAs. To this end, it preserved the requirements of significant political power, independence from states, and the employment of violence in pursuit of its objectives. ${ }^{196}$ But, it also now required that NSAs exercise territorial control rather than "exert influence at a national or international level." Though the addition of territorial control arguably lent greater clarity to the NSA definition than the vague notion of "exert influence", it still left much open to interpretation. For example, how much territory is required, and for how long a duration must it be "controlled"? From this perspective, any clarity gained by the change likely will come at the expense of further reducing the number of NSAs potentially eligible for consideration under IRFA.

The Senate's revisions also included two significant changes to further lessen the likelihood and consistency of presidential action against an NSA designated as an EPC. First, the Senate bill entrenched the House language

${ }^{191}$ Human Rights Committee, General Comment on Freedom of Thought, Conscience and Religion, U.N. Doc. CCPR/C/21/Rev.1/Add.4, at 92 , (1993).

${ }^{192}$ Id. at 5.

${ }^{193}$ Frank R. Wolf International Religious Freedom Act, H.R. 1150, 114th Cong. $\$ 301$ (Nonstate Actor Designations) (as engrossed in Senate, Dec. 10, 2016).

${ }^{194} I d$. at $\S 102$ (Annual Report on International Religious Freedom).

${ }^{195} I d$. at $\S 104$ (Prisoner Lists and Issue Briefs on Religious Freedom Concerns).

${ }^{196} I d$. at $\S 3$ (Definitions) (as engrossed in Senate, Dec. 10, 2016). 
scrapping the requirement of presidential action against EPCs. In particular, it provided that the "President should take specific actions, when practicable, to address [EPC] violations of religious freedom." ${ }^{, 197}$ With this modification, the Senate endorsed the House decision to downgrade presidential action from mandatory to optional ("shall take" to "should take"), and further enabled the president to waive off taking any EPC-targeted action in the event he or she deemed it "impracticable." Coupled with this, the Senate also did away with requiring presidential action targeting EPCs to be based on a pre-approved inventory of sanctions already provided under IRFA $\S 405$. In doing so, the Senate left as open-ended - and thus unpredictable - the potential types of executive action the president might take. Viewed in their entirety, these revisions appeared to further expand presidential discretion and make the likelihood of any EPC action even more remote.

Perhaps to counterbalance the additional attrition to IRFA's new NSA provisions, the Senate preserved the "sense of Congress" that the Secretary of State should work "to create new political, financial, and diplomatic tools" to deal with violations of religious freedom committed by NSAs. To this, it added a new provision recommending that any presidential action targeting an EPC "should also involve high-level diplomacy with the government of the country in which the non-state actor is operating." 198 Presumably, this diplomatic engagement might serve to generate an impact on or consequence for the EPC without the need for direct U.S. action.

Looking beyond the Senate's NSA/EPC-related changes, the new bill continued the retreat away from the vision set out in the original Wolf Act by declining to support additional House-approved amendments intended to strengthen IRFA. While the Senate endorsed the 90-day reporting deadlines introduced in the House version, it deleted the provision requiring countries appearing on the newly created Special Watch List for two consecutive years to be automatically designated as CPCs. Therefore, moving forward, these countries could be placed on the Watch List and remain there indefinitely. ${ }^{199}$ What implications this may have in practice remain to be seen. However, by removing the provision, the Senate rejected at least part of the rationale for establishing a second tier of scrutiny under IRFA. Without the automatic CPC escalation after two years, countries on the Special Watch List arguably are

\footnotetext{
${ }^{197} I d$. at $\S 301$ (Non-State Actor Designations) (as engrossed in Senate, Dec. 10, 2016) (emphasis added).

${ }^{198} \mathrm{Id}$.

199 Compare Frank R. Wolf International Religious Freedom Act, H.R. 1150, 114th Cong. § 302 (Presidential actions in response to particularly severe violations of religious freedom) (as engrossed in Senate, Dec. 10, 2016) with Frank R. Wolf International Religious Freedom Act, H.R. 1150, 114th Cong. at $\S 302$ (Presidential actions in response to particularly severe violations of religious freedom) (as engrossed in House, May 16, 2016).
} 
being put on notice that nothing in particular may happen to their status or standing with the United States in the face of violations of religious freedom that fall below the threshold of "particularly severe."

The Senate also took aim at the IRF Ambassador and IRF Office, further undercutting efforts to boost the role and stature of these institutional actors. The Senate version deleted the nonbinding "sense of Congress" provision recommending that the IRF Ambassador and IRF office be elevated "to the Office of the Secretary, similar to other Ambassador at Large positions." ${ }^{200}$ At the same time, it rejected provisions designed to secure the IRF Office's operational capacity. Specifically, it replaced the explicit House requirement that OIRF have "at least 25 full-time equivalent staff positions" 201 with a far vaguer commitment of "appropriate staff for the Office, including full-time equivalent positions." 202 To soften this blow, a new "sense of Congress" provision was added to the effect "that maintaining an adequate staffing level at the Office, such as was in place during fiscal year 2016, is necessary for the Office to carry out its important work.,"203

Further weakening the institutional actors advocating for religious freedom within the U.S. foreign policy-making process, the Senate diluted what remained of the envisioned NSC special adviser on IRF. The revised Senate bill deleted the House-backed "sense of Congress" provision that communicated an explicit, enlarged status for the special adviser position, including the responsibility for making policy recommendations. Instead, the Senate provision simply explained - albeit removing the nonbinding "sense of Congress" formulation - that the advisor (if appointed) would "assist the Ambassador at Large for International Religious Freedom to coordinate international religious freedom policies and strategies." ${ }^{204}$

\footnotetext{
${ }^{200}$ Compare H.R. 1150, $\$ 101$ (Office on International Religious Freedom; Ambassador at Large for International Religious Freedom) (as engrossed in House, May 16, 2016) with H.R. $1150, \S 101$ (Office on International Religious Freedom; Ambassador at Large for International Religious Freedom) (as engrossed in Senate, Dec. 10, 2016).

${ }^{201}$ H.R. 1150, § 101 (Office on International Religious Freedom; Ambassador at Large for International Religious Freedom) (as engrossed in House, May 16, 2016).

${ }^{202}$ H.R. 1150, § 101(a)(3) (Office of International Religious Freedom; Ambassador at Large for International Religious Freedom) (as engrossed in Senate, Dec. 10, 2016) (emphasis added). This arguably is an improvement on the original IRFA language which provided that "[t]he Secretary of State shall provide the Ambassador at Large with such funds as may be necessary for the hiring of staff for the Office, for the conduct of investigations by the Office, and for necessary travel to carry out the provisions of this section." Id.

${ }^{203} \mathrm{Id}$.

${ }^{204}$ Compare H.R. 1150, $\$ 201$ (Special Adviser for International Religious Freedom) (as engrossed in Senate, Dec. 10, 2016) with H.R. 1150, § 201 (Special Adviser for International Religious Freedom) (as engrossed in House, May 16, 2016).
} 
The Senate also introduced subtle changes to the provisions governing mandatory training of State Department personnel and the funding of religious freedom promotion activities. With respect to training, the Senate bill appeared to preserve its mandatory nature, as well as the one-year time frame for initiating a curriculum, the personnel required to participate, and the specific courses that would incorporate religious freedom training. However, it modified House language directing that the National Foreign Affairs Training Center "shall begin mandatory training on religious freedom for all Foreign Service officers . . . ." Instead, it provided that the training center "conduct training on religious freedom for all Foreign Service officers . . ."205 Further, it deleted language specifying that training "be a separate, independent, and required segment" of the courses designated.

The Senate also transferred the obligation to develop a training curriculum from the Secretary of State to the IRF ambassador, directing that the ambassador "shall make recommendations to the Secretary of State regarding a curriculum for the training of United States Foreign Service officers." 206 In addition, the new bill restored previously deleted language regarding the sharing of training materials. Rather than merely suggest that the "curriculum and training materials developed . . . should be made available to all other Federal Agencies," the Senate version reverted to a more mandatory and detailed formulation. Borrowing from the bill as originally introduced, it provided that the curriculum and materials "shall be shared with the United States Armed Forces and other Federal departments and agencies with personnel who are stationed overseas, as appropriate." 207

With respect to funding activities promoting international religious freedom, the Senate opted to preserve the provision's noncompulsory "sense of Congress" formulation. However, it modified the House proposal suggesting the "Department of State should make available" minimum amounts from the Human Rights and Democracy Fund for such activities and for the establishment of a Religious Freedom Defense Fund. Instead, it recommended that the "President should request sufficient appropriations from Congress to support" these activities. ${ }^{208}$

Despite the numerous modifications reducing the overall scope of the draft Wolf Act, the Senate still retained several key proposed amendments contained in the House version. First, it left intact the provisions governing the

\footnotetext{
${ }^{205}$ Frank R. Wolf International Religious Freedom Act, H.R. 1150, 114th Cong. §103 (Training for foreign service officers) (as engrossed in Senate, Dec. 10, 2016).

${ }^{206} I d$.

${ }^{207} I d$. The provision also detailed several specific religious freedom-related issues that would be relevant across these departments and agencies.

${ }^{208} I d$. at $\S 401$ (Assistance for Promoting Religious Freedom).
} 
new Designated Persons List for Particularly Severe Violations of Religious Freedom, only making changes focused on streamlining language. It preserved the obligation for the Secretary of State to maintain and update the list, as well as the requirement to provide Congress with reports on updates to the list every 180 days. The preservation of this list in the draft bill signaled the possibility for a more active but tailored use of targeted action intended to punish individuals responsible for particularly severe violations of freedom of religion. $^{209}$ Additionally, this reporting requirement holds the potential for providing Congress with a new tool for measuring how seriously the State Department is taking its obligation to protect and promote religious freedom. In addition, the Senate maintained the "sense of Congress" provision suggesting that the president's annual national security strategy report should "promote international religious freedom as a foreign policy and national security priority" in part because it "protects other, related human rights, and advances democracy outside the United States." ${ }^{210}$ This provision traced back to H.R. 1150 as originally introduced nearly two years earlier.

The Senate also preserved new House language incorporating explicit protection for theistic and non-theistic views under the umbrella of freedom of religion or belief. In addition, it retained the creation of a Victims List to be maintained by USCIRF. According to this provision, the Commission would publicize a list of individual victims harmed by governments and NSAs USCIRF has recommended for CPC and EPC designation respectively.

The most notable addition provided in the Senate version of the Wolf Act came in the form of a new finding that a "policy or practice of routinely denying applications for visas for religious workers in a country can be indicative of a poor state of religious freedom in that country." 211 This finding was supplemented by a new "sense of Congress" statement recommending that the "United States Government should seek to reverse any such policy by reviewing the entirety of the bilateral relationship between such country and the United States." 212

\section{Public Law 114-281: Outcome of Congressional Negotiations}

Shortly after the dust of negotiations in Congress settled, President Obama signed the Frank R. Wolf International Religious Freedom Act, enacting the most extensive changes to IRFA since its inception nearly two

\footnotetext{
${ }^{209}$ Id. at $§ 501$ (Designated Persons List for Particularly Severe Violations of Religious Freedom).

${ }^{210}$ Id. at $\S 703$ (Sense of Congress Regarding National Security Strategy to Promote Religious Freedom Through United States Foreign Policy).

${ }^{211} I d$. at $\S 2$ (Findings, Policy, Sense of Congress).

${ }^{212} I d$
} 
decades earlier. Although the final law fell far short of its original vision, it did pick up a handful of improvements along the way. Most notably, while the provisions governing the ability of IRFA to scrutinize NSAs benefitted from significant clarification, they were also subject to much claw back and attenuation. Representatives Ed Royce and Chris Smith initially lauded the proposed IRFA amendments for targeting groups that "have turned religious intolerance into a murderous force of global instability" ${ }^{213}$ and were responsible for "some of the most egregious religious freedom violations." ${ }^{214}$ But by the time the Senate completed its revisions, much of the thunder behind the soughtafter ability to identify and sanction NSAs - including the requirement that the president take defined actions against EPCs and the inclusion of NSAs on the new Special Watch List - had either been significantly diminished or altogether deleted from the bill. The provisions that remain are likely to generate interpretational confusion and conflict that risk further clouding the effectiveness and consistency of any EPC outcomes. These ambiguities impact many obvious but decisive questions. For example, when does an NSA exert "significant" political power? What amount of territorial control is necessary? What degree of independence is sufficient to demonstrate autonomy from a sovereign government? How much violence must an NSA exert, and relatedly, what NSA actions will rise to the level of "severe" for an EPC designation? Finally, what guidance ought to apply concerning the design of any presidential actions to be taken against any designated EPCs?

Examining the final Wolf Act more generally betrays the same overarching tendency to delete or otherwise reduce the potential effectiveness of the various provisions originally proposed. As noted above, the effort to place a cap on the duration of the president's ability to waive mandatory action against CPCs did not make it into the final law. Failing to secure this amendment likely will perpetuate chronic CPC-designated states continuing to remain under an indefinite waiver based on "important national interest." Related to this, Congress undid other efforts to place a check on executive discretion. For example, by rejecting provisions intended to secure USCIRF's extended reauthorization and requiring the president to explain any decision to forgo a CPC designation where USCIRF had made a prior recommendation, the final Wolf Act declined to scale back the executive discretion that has come to define IRFA over its twenty years of implementation.

Similarly, Congress dismantled proposals intended to better integrate religious freedom into U.S. foreign policy. It rejected requiring the president to appoint an NSC adviser on international religious freedom and the creation of two new NSC interagency committees that would have provided a central

${ }^{213}$ CONG. REC. H2399, H2403 (May 16, 2016) (statement of Rep. Royce).

${ }^{214}$ CONG. REC. H7580, H7584 (Dec. 13, 2016) (statement of Rep. Smith). 
policy-input role for the IRF Ambassador. Given IRFA's history, it is unlikely that such an NSC appointment will occur without more than a "sense of Congress" recommendation supporting it. Coupled with this, Congress also rejected the small but telling proposal to upgrade the IRF ambassador's role from "a" principal advisor to "the" principal advisor to the president on religious freedom issues.

Further undercutting IRFA's institutional structures, Congress eschewed relocating the IRF office and ambassador to the Office of the Secretary of State. So powerful was the unwillingness to situate the IRF office within the Office of the Secretary, that the Senate even struck the House's proposed solution, which simply relegated the OIRF move to a nonbinding "sense of Congress" recommendation. The Senate's deletion of this compromise provision was made even starker by the fact that it simultaneously rejected the House's justification for the move. According to the House, the relocation would "demonstrate both the strategic importance of international religious freedom policy within the State Department bureaucracy and show persecuted religious groups globally that the U.S. gives priority to the protection and promotion of international religious freedom." ${ }^{215}$ Together with these telling omissions, the final Wolf Act likewise rejected clear statutory guarantees governing staffing and funding levels for OIRF and representational funds for the ambassador.

The Senate also diluted the primary function of the newly minted Special Watch List by deleting the mandatory escalation to CPC status for countries remaining on the Watch List for two years. With this decision, it finished the job started by the House, which had already moved to delete the inclusion of NSAs on the list. As it stands, the new tier system under IRFA may give rise to a situation whereby a country falling just below the threshold of particularly severe violations of freedom religion remains on the Watch List without any imminent consequence or real impetus to engage diplomatically to resolve or mitigate violations.

Still, viewed in its entirety, the Wolf Act does hold out some potential for at least a partial revival of IRFA's mandate. First, IRFA now enables the designation of EPCs and - though not mandatory—formally opens the door to presidential measures targeting these violent nonstate actors. Second, the IRF ambassador is now empowered to report directly to the Secretary of State, creating at least one significant opening for advocacy and dialogue that potentially places religious freedom issues alongside other core foreign policy concerns. Cementing this, the ambassador is also newly designated as

${ }^{215}$ Frank R. Wolf International Religious Freedom Act, H.R. 1150, 114th Cong. § 101 (Office on International Religious Freedom; Ambassador for International Religious Freedom) (as engrossed in House, May 16, 2016). 
"the" principal advisor to the Secretary of State on matters affecting religious freedom abroad. Third, the final amendments leave intact major provisions related to training State Department officials, a long-sought after objective of USCIRF and others. ${ }^{216}$ These new training requirements amend the Foreign Service Act to include mandatory "training on religious freedom for all Foreign Service officers, including all entry level officers." They further empower the IRF Ambassador, in consultation with USCIRF, to make recommendations to the Secretary of State regarding the nature of the curriculum, including "how United States international religious freedom policy should be carried out in practice by United States diplomats and other Foreign Service officers." 217 If this training curriculum is substantive and executed effectively, it will address one of the longest-standing criticisms regarding implementation of IRFA.

Similarly confirming the Congress' readiness - if incrementally-to buttress the effectiveness of IRFA, the final law incorporates firm deadlines for presidential reporting and designating of CPCs. These new deadlines signal Congress' intent to police IRFA's operation more closely and close loopholes that previously had diminished the effectiveness of the reporting mechanism by tolerating periods of either late or altogether missed reporting and designation. Likewise, creation of a new tier system under IRFA through the Special Watch List furnishes the president with the ability to draw more nuanced distinctions among those states falling short of CPC status. Moreover, even though a state's inclusion on the Watch List no longer comes with the built-in specter of looming sanction, if harnessed effectively, it may still serve to put states on notice and induce diplomatic engagement focused on improving religious freedom conditions. ${ }^{218}$

Lastly, the Wolf Act operates to clarify and deepen IRFA's understanding of freedom of religion and provide tools for more consistently keeping the spotlight on victims of religious freedom violations. With respect

\footnotetext{
${ }^{216}$ As Hertzke concluded ten years ago, "efforts to strengthen the law seem warranted. Congress could mandate that a religious freedom specialist be appointed to the National Security Council. Congress could elevate the State Department Office and integrate its work with other diplomatic operations. Broader religious training for diplomatic personnel could be required." Hertzke, supra note 57, at 22-23.

${ }^{217}$ Frank R. Wolf International Religious Freedom Act, Pub. L. No, 114-281, § 103, 130 Stat. 1426 (2016) (codified at 22 U.S.C. § 6401). IRFA's original amendments to the Foreign Service Act are general in nature, focusing on "instruction in the field of internationally recognized human rights." International Religious Freedom Act of 1998, Pub. L. No. 105292, §104, 112 Stat. 2787, 2790 (1998) (codified at 22 U.S.C. § 6413).

${ }^{218}$ See generally Frank R. Wolf International Religious Freedom Act, H.R. 1150, 114th Cong. (2015).
} 
to the scope of freedom of religion, moving forward, IRFA now explicitly recognizes that the right to freedom of thought, conscience, and religion includes protection for the "non-theistic . . . . beliefs and the right not to profess or practice any religion." 119 It also identifies a "policy or practice of routinely denying applications for visas for religious workers" as indicative of a potentially "poor state of religious freedom" in a given country. ${ }^{220}$ Finally, with respect to keeping a spotlight on victims of religious freedom violations and flagging violators, the Wolf Act introduced new, if imperfect, tools. Most notably, the Victims List, managed by USCIRF, ${ }^{221}$ and the Designated Persons List, managed by the State Department, hold new potential for naming and shaming as well as for deterring states from violating religious freedom norms from the outset.

\section{CONCLUSION}

The Wolf Act obtained the unopposed endorsement of the House and Senate as well as the approval of President Barak Obama. However, this moment of bipartisan buy-in came at the expense of casting off or downgrading several significant provisions contained in the bill's original text. In the end, negotiations over the Wolf Act amendments to IRFA underscore the extent to which the United States' promotion of international religious freedom remains a contested area. Despite assurances that the Act helps ensure "that defending religious freedom remains at the core of our engagement... and that we have the most effective policies in place to be successful,, 222 the failure to adopt key reforms signals a continuing unease with fully integrating religious freedom promotion into U.S. foreign policy.

The ambivalent outcome hanging over the Wolf Act is encapsulated in how Congress opted to address the challenge of violent nonstate actors (NSAs). IRFA now includes a framework for identifying violent NSAs committing violations of religious freedom and enabling the president to designate those engaging in particularly severe violations as "Entities of Particular Concern" (EPC). However, while it may be tempting to draw a parallel between IRFA's sanction-triggering "Country of Particular Concern" (CPC) designation and this new EPC designation, the similarity is superficial at best. As the legislative history assessed above demonstrates, in the quest

\footnotetext{
21922 U.S.C. § 6401(a)(3) (2016). See also Human Rights Committee, supra note 191.

22022 U.S.C. $\$$ 6401(a)(4) (2016).

22122 U.S.C. $\$ 6417(d)(1)(2016)$.

222 Press Release, Senate Foreign Relations Committee, Corker Praises Committee Passage of Religious Freedom Bill (Dec. 6, 2016), https://www.foreign.senate.gov/press/chair/release/cork er-praises-committee-passage-of-religious-freedom-bill [https://perma.cc/8FYX-B98W].
} 
to secure passage of the Wolf Act, Congressional negotiations stripped much of the substance intended to mirror the $\mathrm{CPC}$ regime from the new provisions applicable to nonstate actors. In place of a system that defines clear outcomes for EPCs, IRFA has been left with a framework riddled with ambiguities virtually guaranteeing uncertainty of outcome. Not only will it be difficult to consistently identify NSAs that qualify for scrutiny under IRFA, but the president will not be obligated to act against those designated as EPCs.

The same ambivalence is manifested elsewhere in the amendments. For example, the final Wolf Act made only incremental improvements to the status of the IRF Ambassador and the IRF Office, and stripped efforts to secure USCIRF's extended reauthorization. These claw backs functioned to preserve executive discretion and reject other major changes intended to drive home the promotion of international religious freedom as a central component of U.S. foreign policy. At the same time, Congress did authorize mandatory religious freedom training for State Department officials. This training, if effectively designed and implemented, should have an overall impact on better integrating religious freedom concerns within the nation's larger foreign policy enterprise. $^{223}$ Likewise, new tools such as the Designated Persons List and Victims List will provide IRFA with new levers of engagement with recalcitrant states and nonstate actors alike. However, the Special Watch List system intended to put states and NSAs on notice - and backed by a tangible potential for CPC designation - ultimately fell appreciably short of the original vision set out in early 2015. Finally, while IRFA now includes the express recognition that freedom of religion includes protection for non-theistic and atheistic beliefs, it remains beset with unenforceable "sense of Congress" provisions. These provisions arguably set the stage for potentially more muscular future action by Congress. However, the persistence of IRFA's original "sense of" provisions and their continued non-enforcement dampens the likelihood of such an outcome.

Whether these overdue amendments to IRFA will engender meaningful changes to the status quo will depend on a variety of elements. First, whether the newly appointed IRF ambassador can effectively assert the office's new

\footnotetext{
${ }^{223}$ An October 2018 report prepared by the State Department's Office of Inspector General (OIG) found only "partial progress" in implementing the Wolf Act. INSPECTION OF THE BUREAU OF DEMOCRACY, HuMAN RightS, AND LABOR, U.S. DEPT. OF STATE 8 (2018), https://www.stateoig. gov/system/files/isp-i-19-11_1.pdf. OIG determined that while DRL "implemented key provisions of the Act," there were "deficiencies related to training, reporting structure, media support, and foreign assistance coordination." Id. Specifically on training, it concluded the State Department "was behind schedule in meeting requirements to develop international religious freedom training for all Foreign Service officers . . . During the inspection, the Office of International Religious Freedom prepared two of five proposed modules for an online course to fulfill this requirement but had yet to complete the remaining three modules. Without these additional modules, the Foreign Service Institute was unable to conduct the training, as mandated by law." Id.
} 
responsibilities and profile; second, whether the new Secretary of State elects to vigorously implement the Wolf Act's new powers, including the ability to sanction NSAs; and third, whether the president communicates a clear interest in vigorously promoting religious freedom as a foreign policy priority, including by prioritizing funding for international religious freedom promotion activities and instituting meaningful sanctions against designated CPCs and EPCs.

Successfully effectuating change across these elements will hinge at least in part on the role played by human rights and religious freedom activists. In regard to this latter point, the Wolf Act provides several ready yardsticks that may prove useful for measuring the extent to which any of its changes are impacting the promotion of international religious freedom. Moving forward, scholars, activists and policymakers alike can turn their attention to assessing, for example: the scope and nature of funding afforded to international religious freedom activities; the extent of the IRF Ambassador's inclusion in the policymaking process; the timing and substance of CPC and EPC designation processes, including the types of action taken; the countries that are added to the Special Watch List, the nature of engagement that follows, and the duration of their designation as such; the content and execution of the State Department's religious freedom training curriculum; the timely and consistent release of the Designated Persons List; and the ongoing interaction between the State Department and USCIRF, including the status of the Commission's future reauthorization. These metrics should serve as revealing bellwethers of where international religious freedom promotion is headed in a post-Wolf Act era. As such, they will also attest to whether the Wolf Act has truly served to "strengthen[] and modernize[]" IRFA "and promote and advance the universal human right of religious freedom around the world," 224 or whether another effort on the part of Congress will be required. ${ }^{225}$

224 Press Release, Marco Rubio, Rubio's International Religious Freedom Bill Heads to President's Desk (Dec. 13, 2016), https:/www.rubio.senate.gov/public/index.cfm/pressreleases?ID=629CFEBD-835E-4984-A188-DBF1E556E69D [https://perma.cc/UR3H-98NZ]. An earlier Rubio press release highlighted Wolf Act amendments to IRFA that the Senate ultimately scrapped, including the mandatory transfer of Special Watch List countries to CPC designation and a minimum staffing guarantee for the IRF Office. Press Release, Marco Rubio, Rubio Introduces Bill To Strengthen Promotion of International Religious Freedom (Apr. 28, 2016), https://www.rubio.senate.gov/public/index.cfm/press-releases?ID=648D5EF2-81EE-4 E77-BC94-CDA8B3EAC16A [https://perma.cc/3SQ3-L2WK].

225 Already, some in Congress continue to pursue many of the proposed amendments lost during negotiations over the Wolf Act. One such proposed resolution reaffirms the commitment of the United States to promoting religious freedom, and calls on the president to "direct grants ... towards civil society that are implementing innovated programs" aimed at promoting and safeguarding religious freedom and to "develop an action plan on international religious freedom and to integrate that plan into United States diplomatic, development, and national security strategies." S. Res. 162, 115th Cong. (2017) (introduced). 
